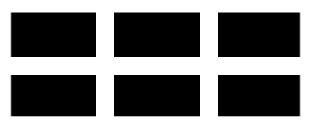

THE WILLIAM DAVIDSON INSTITUTE AT THE UNIVERSITY OF MICHIGAN BUSINESS SCHOOL

A re-examination of the Purchasing Power Parity using non-stationary dynamic panel methods : a comparative approach for developing and developed countries

\author{
By: Imed Drine and Christophe Rault
}

William Davidson Working Paper Number 570

May 2003 


\title{
A re-examination of the Purchasing Power Parity using non-stationary dynamic panel methods : a comparative approach for developing and developed countries.
}

\author{
Imed DRINE*(EUREQua, Sorbonne University), \\ Christophe RAULT ${ }^{\dagger}$ (EPEE, Evry University and EUREQua)
}

April 2, 2003

\begin{abstract}
The aim of this paper is to apply recent advances in the econometrics of non-stationary dynamic panel methods to examine the robustness of the PPP concept for a sample of 73 developed and developing countries. Our investigations indicate that the strong PPP is verified for OECD and MENA countries. However in Africa, Asia, Latin America and the PECO, PPP does not seem relevant to characterize the long-run behavior of the real exchange rate. A widening of our analysis field shows that the nature of the exchange rate regime doesn't condition the validity of the PPP and that the PPP is more easily accepted in countries with high inflation than with low one.

Key words : Purchasing power parity, real exchange rate, developed country, developing country, panel unit-root and cointegration tests.
\end{abstract}

JEL Classification : E31, F0, F31, C15.

*Paris I, Maison des Sciences de l'Economie, 106-112 bd. de L'Hôpital, 75647 Paris Cedex 13, France. E-mail :drine@univ-paris1.fr

†University of Evry-Val d'Essonne, Département d'économie, Boulevard François Mitterrand, 91025 Évry Cedex, France. E-mail : chrault@hotmail.com 


\section{Introduction}

The aim of this paper is to re-examine one of the most controversial theories in international economics- the purchasing power parity (hereafter PPP) for developing and developed countries, by using recent advances in the econometrics of non-stationary dynamic panel methods. The PPP in its different versions relates the nominal exchange rate between any two currencies and the relative price levels in the respective countries. The implication is that a country with a higher inflation than its trading partner will tend to have a depreciating currency. Although this theory is often not empirically supported by data and although its relevance as a benchmark to describe the long term behavior of the real exchange rate has been questioned, the PPP has continued to be pervasive in macroeconomic models. The PPP is implicit and also explicit in many exchange rate determination models, and is also used as a yardstick of the openness of an economy in macro-economic models. On the policy front, PPP based benchmarks have been used to assess levels of exchange rates in a bid to establish the need, extent and direction of adjustment.

Very recently the debate on the question of the PPP validity in the longrun has re-emerged mainly in developed countries (see for instance Canzoneri, Cumby and Diba, 1996; Obstfeld and Taylor, 1996; Pedroni, 1995; Taylor, 1996). According to the numerous reviews of literature on this subject, this renewal of interest for the PPP is essentially due to three factors: (1) the necessity to reinterpret the PPP theory, (2) the availability of long time series, and (3) the development of panel data econometrics (cf. notably Breuer, 1994; Froot and Rogoff, 1995; Rogoff, 1996).

These works also indicate that the interaction between these three factors has produced some stylized facts of the real exchange rate behavior in developed countries: (1) the hypothesis that the real exchange rate follows a random walk is strongly rejected by data in the long run, (2) the real exchange rate tends to return to its equilibrium level as defined by the PPP although we observe persistent PPP deviations (Wei and Parsley, 1995), (3) the weak PPP (i.e. the 
existence of a long-run relationship between the nominal exchange rate and relative price levels) is generally empirically accepted, (4) with the exception of the yen $/ \$$ exchange rate, there are no permanent deviations of the real exchange rate with regard to the PPP which can be explained by structural factors, such as the Balassa-Samuelson effect.

In this paper we use recent advances in the econometrics of non-stationary dynamic panel methods to examine the relevance of the PPP concept as an equilibrium real exchange rate determinant in developing countries. Our econometric methodology rests upon the panel data integration tests proposed by Im, Pesaran and Shin (1997) and on the panel data cointegration tests recently developed by Pedroni (1997, 1999, 2000, 2001). We consider a sample of 73 developing countries classified according to three criteria (the development level and the geographic zone, the nature of the exchange rate regime, the level of inflation) and we analyze whether the economic specificities have an influence or not on the long-run the real exchange rate behavior. This allows us to draw more general conclusions on the robustness of the PPP. As a comparison we also introduce a group of developed countries. Our study is justified for at least 3 reasons :

- First of all, there only exists few works on developing countries that use the recent advances in the econometrics of non-stationary dynamic panel methods in comparison with the studies on developed ones, and these works do not always lead to clear conclusions concerning the validity or not of the PPP. Indeed, the choice of the period of study, the countries and the price indices largely condition the empirical results. Nagayasu (1998), for instance, empirically confirmed by applying the cointegration tests of Pedroni's (1995) the semi-strong form of the PPP for 16 African countries using annual data covering the 1981-1994 period. Holmes (2000 ) found by applying the unit root test of Im and al (1997) to a sample group of 27 African countries on quarterly data covering the 1974-1997 period that the PPP is verified for countries with high inflation. 
- Then, the economic specificities of developing countries make us think that the real exchange rate characteristics of these countries can differ from those of developed countries, whose regularities have recently been put in evidence in literature (cf. infra).

- Finally, the recent developments of panel data econometrics (cf. notably Pedroni, 1997, 1999, 2000, and 2001) now allow us to remedy the low power of the conventional time series econometric techniques in small samples and hence to obtain more robust results.

The remainder of the paper is organized as follows. In the second section we describe the theoretical relationships to be tested as well as the field of our study ( the choice of countries, indicators, the sample period). In section 3 we expose the panel data unit root tests and panel cointegration methodology that will be used in the empirical application. In section 4 we report and comment our econometric results for a panel of 73 developing and developed countries. A final section reviews the main findings. Two main results emerged from our analysis. First, the PPP does not seem relevant to characterize the long-run behavior of the real exchange rate in most developing countries. Second, the PPP is more easily accepted in countries with high inflation than with low one, but the nature of the exchange rate regime doesn't condition its validity.

\section{The theoretical relationships to be tested and the field of the study}

The PPP hypothesis is usually expressed by a long-run relationship between the nominal exchange rate and the relative price levels. Under the strong PPP, the cointegration coefficient between the nominal exchange rate and the relative price levels is equal to one, while under the weak PPP, the two variables are cointegrated but the cointegrating vector can differ from unity. In this second case, an equilibrium mechanism may exist assuring a symmetric movement of the two variables, but the differences in the construction of price indices, the 
transaction costs (distance) and many other nuisance factors can lead to a nonunitary relationship ${ }^{1}$. Given that the cointegrating vector between the nominal exchange rate and the relative price levels is unitary, the strong PPP can be investigated by testing whether the real exchange rate is stationary or not. The presence of a unit root will imply that the PPP does not hold in the long run. On the other hand the weak PPP holds if the nominal exchange rate and the relative price levels are cointegrated independently of the cointegrating vector nature. We therefore consider two levels of quantitative evaluation of this hypothesis in a long-run perspective :

- at a first level, it is investigated by testing whether the real exchange rate logarithm is stationary or not,

- at a second level, we test if the variable $e_{t}-\alpha-\beta\left(p_{t}-p_{t}^{*}\right)$ is stationary or not, where $\alpha$ and $\beta$ are constant parameters which can differ between countries, $e_{t}$ being the logarithm of the nominal exchange rate, $p_{t}$ the logarithm of the domestic prices and $p_{t}^{*}$ the logarithm of foreign prices.

Besides, many applied works show that the PPP validity largely depends on the sample groups of countries considered, the period of study, as well as the type of data used. The PPP would be more easily accepted for developed countries than for developing ones, especially for the posterior 1973 period, when the Bretton Woods System ended. Moreover, some works reveal that certain econometric results can be explained by the exchange rate regime instability. Rogoff (1996) noticed that the problem of the exchange rate regime instability related to the use of long time series strongly conditioned the econometric results. Besides, Mussa (1986) indicated that the real exchange rate volatility depended on the exchange rate regime adopted. Furthermore, certain studies show that the PPP is more likely to hold in opened countries with low inflation. Indeed, countries with high inflation generally suffer from an exchange rate instability and constitute a priori good examples of PPP refutation. On the other

${ }^{1}$ See for instance Fisher and Park (1991) or Taylor (1988). 
hand, other works confirm, that given the predominancy of nominal shocks in economies with high inflation, PPP deviations tend to reduce quicker than in economies with low inflation. In addition, Froot and Rogoff (1995) stressed that nothing guarantees that the weak PPP holds in low inflation countries because real shocks can modify the goods relative prices.

These conclusions are still the object of debate and very few empirical studies have been done. Furthermore, it seems difficult to verify if at least a part of these results is not actually due to the low power of the conventional econometric methods in small samples. The recent developments of panel data integration and cointegration techniques allow us henceforth to bridge up this gap and to re-assess the validity of the PPP concept for developing countries.

In addition to these theoretical considerations, panel data integration and cointegration techniques require a minimum of homogeneity to lead to robust conclusions. This is the reason why we decompose our sample of 73 countries into several homogeneous sub-groups. Three criteria were chosen to operate this classification $^{2}$ :

- firstly, the level of development and the geographic zone: our study deals with five groups of developing countries ${ }^{3}$ : Africa, Latin America, Asia, the Middle East and North African (MENA) countries, Central and Oriental Europe countries (PECO) and a group of developed countries (OECD).

- secondly, the type of exchange rate regime: We classified countries in two groups, those with a fixed exchange rate regime and those with a more or less flexible one ${ }^{4}$.

- thirdly, the inflation level : Two groups of countries were thus defined,

\footnotetext{
${ }^{2}$ As most countries composing our sample are strongly opened to international trade, we do not proceed to a decomposition according to the openness degree.

${ }^{3}$ The list of countries considered in our empirical investigation is provided in the appendix.

${ }^{4}$ Countries with intermediate and flexible exchange rate regimes are classified together. The grouping of countries also takes the exchange rate regime stability for a given period into account. Hence, we decomposed the period into two sub-periods from 1970 to 1983 and from 1990 to 1997. The countries for which the exchange rate regime is strongly unstable are excluded from the sample. For the first sub-period the countries classification is made according to an index that we calculated. For the second sub-period we referred to the work of Levy-Yeyati and Sturzenegger (1999).
} 
those with a low inflation level and those with a high inflation one $\mathrm{e}^{5}$.

The sample period differs according to the group of countries and according to the indicator of the real exchange rate considered. Two indicators of the real exchange rate were used :

1. the multilateral real exchange rate with regard to the main trading partners (effective real exchange rate).

2. the bilateral real exchange rate defined as the ratio of domestic consumption prices and the stock prices in the United States.

This choice of price indices is related to the two well-known PPP approaches. On the one side, if we consider an approach in terms of the law of one price, it seems preferable to retain stock prices because they take better tradable goods into account. However, the absence of data for stock prices in developing countries constrained us to only retain consumption prices. This real exchange rate indicator is perfectly in accordance with the conventional theoretical models where the real exchange rate is defined as the ratio of the tradable and nontradable goods prices. Indeed, it is generally admitted that consumption prices contain more non-tradable goods than stock price indices. On the other hand, if we conceive the PPP in the currency quantitative theory view, it is better to retain the consumer price index. The exchange variations are then connected to those of the currency purchasing power. We then use the effective real exchange rate, because it represents better by construction the various trading partners. Note that we consider various real exchange rate indicators because the point here is not to take part in the debate on the PPP concept and confirm a par-

\footnotetext{
${ }^{5}$ Countries are assumed with a high inflation rate when the average prices variation exceeds $10 \%$ by years. In that case we also selected countries according to the inflation level stability for the period. The countries for which the inflation level has strongly varied during the period were excluded from the sample. We proceeded as follows: we decomposed our period of study into two sub-periods, 1970-1989 and 1990-1997 and calculated the average level of inflation for each period. The countries for which the average inflation has considerably varied between the two sub-periods were excluded from the sample. Only the countries which have a stability of their average inflation level between the two sub-periods were taken into account.
} 
ticular approach. Our objective consists on the contrary in testing the validity of the PPP whatever the notion from which it comes from.

It remains to add, as indicated by Levin and Lin $(1993)^{6}$ that working with panel data on groups of countries which are more or less homogeneous poses the problem of the interdependence between countries reflecting the presence of common factors (due for instance to the fact that all the nominal exchange rates are expressed with regard to the dollar). This phenomenon of interdependence between countries affects the test results and the estimated long-run coefficients. Indeed, O Connell (1998) showed that the PPP tests which ignore this phenomenon suffer from important distortions. Consequently, tests are here implemented both on the unadjusted and adjusted data ${ }^{7}$.

The series of effective real exchange rate are extracted from the French database of the CEPII and cover the 1964-1998 period. The series of consumption and stock prices indices, the nominal exchange rate (expressed in dollar) are extracted from the CHELEM data base of the CEPII and cover the 1970-1998 period except for Africa where, due to the lack of data, it only concerns the 1983-1998 period. For the PECO, the price and nominal exchange rate series are quarterly and span the 1990:1-1998:4 period. Data are obtained from the OECD data base, from the World data base on transition countries (WIIW) and from national financial statistics. The real exchange rate is expressed with regard to the DM given the importance of the trading exchange of these countries with Germany.

\section{The non-stationary dynamic panel economet- ric methodology}

Before the development of econometric techniques adapted to non-stationary dynamic panels, previous studies on panel data implicitly supposed that the

\footnotetext{
$6 "$ Since the removal of cross - section averages from the dated does not affect the limiting distributions of the sample group unites root and cointegration test statistics, this step should be performed unless there are strong a priori reasons to expect the unadjusted dated to be independent across individuals ", Levin and lin (1993).

${ }^{7}$ The adjustment is made by deducting for each serie at each date the average of the group.
} 
variables used were stationary. This constitutes a serious limitation to their results given the considerable bias existing in this case on the parameter estimates when the non-stationarity properties of data are not taken into account. Due to the recent developments of econometrics, it is henceforth possible to test stationarity on panel data as well as the degree of integration of set of variables. We now present the panel unit root tests and panel cointegration tests that we will use in the empirical application reported in section 4.

\subsection{Panel unit root tests}

Initial methodological work on non-stationary panels focused on testing unit roots in univariate panels. Quah (1994) derived standard normal asymptotic distributions for testing unit roots in homogeneous panels as both time series and cross sectional dimension grow large. Levin and Lin (1993) derived distributions under more general conditions that allow for heterogeneous fixed effects and time trend. More recently, Im, Pesaran and Shin (1997), studied the small properties of unit root tests in panels with heterogeneous dynamics and proposed alternative tests based on the mean of individual unit-root statistics. In this paper we shall apply Im, Pesaran and Shin (1997) unit-root test (called IPS after) since it is more powerful than those of Quah (1994) and Levin and Lin (1993) used in existing studies.

Levin and Lin's test is considered as more general than those of Quah since it explicitly takes heterogeneity and correlation between units into account. However as shown by Papell (1997) it suffers from size distortion without being able to correct serial correlation adequately. Using Monte Carlo simulations, he showed that the finite sample critical values are greater than those in Levin and Lin (1993). For quarterly data, the critical values are $11 \%$ higher (on average) than those reported by Levin and Lin and for monthly data, they are $3 \%$ higher.

The test proposed by Im, Pesaran and Shin (1997) permits to solve Levin and Lin's serial correlation problem in assuming heterogeneity between units in a dynamic panel framework. Furthermore as shown by Im and al via Monte Carlo simulations it has higher power than that of Levin and Lin. IPS (1997) 
proposed two statistics : a Maximum Likelihood Statistics, called Lbar, and a Student statistic tb. These two statistics are based on individual Augmented Dickey-Fuller (ADF) regressions. Since an appropriate ADF regression will correct the serial correlation in data, the IPF panel unit-root test takes care of serial correlation automatically. In our empirical work of section 4 we shall use the tb statistic instead of the Lbar one since IPS's Monte Carlo experiments have shown that it is the more powerful even for a value of $\mathrm{N}$ inferior to 5 . This statistic can be expressed as :

$$
t_{b}=\frac{\sqrt{N}\left(t_{N T}-E\left(t_{T}\right)\right.}{\sqrt{\operatorname{Var}\left(t_{T}\right)}}
$$

where $t_{N T}=\frac{1}{N} \sum_{i=1}^{N} t_{i T}$ is an average of the $\mathrm{t}$ individual student statistic in a conventional time series unit-root analysis, $E t_{T}$ and $V\left(t_{T}\right)$ are respectively the mean and variance of $t_{i T}$ under the null hypothesis that the series are integrated of order one with $\mathrm{N} \rightarrow \infty$.

IPS show that under the null hypothesis of non-stationarity, the $t_{b}$ statistic follows the standard normal distribution asymptotically.

\subsection{Panel cointegration tests}

In the empirical application we shall apply Pedroni's cointegration test methodology (1995a, 1997 and 1999) to analyze the Balassa-Samuelson hypothesis. Pedroni (1995a) studied the properties of spurious regressions and tests for cointegration in heterogeneous panels and derived appropriate distributions for these cases. These allow us to test for the presence of long run equilibria in multivariate panels while permitting the dynamic and even the long run cointegrating vectors to be heterogeneous across individual members. Like the IPS panel unit-root test, the panel cointegration tests proposed by Pedroni also take heterogeneity into account using specific parameters which of course are allowed to vary across individual members of the sample. Pedroni (1997 and 1999) derived the asymptotic distributions and explored the small sample performances of seven different statistics to test panel data cointegration. Of these 
seven statistics, four are based on pooling along, which is often referred to as the Within dimension (called "panel" after), and the last three are based on the Between dimension (called "group" after). These different statistics are based on a model that assumes that cointegration relationships are heterogeneous between individual members and are defined as :

\section{For the Within statistics}

$$
\begin{gathered}
Z_{\rho}^{w}=\left(\sum_{i=1}^{N} \sum_{t=1}^{T} L_{11 i}^{-2} \hat{e}_{i t-1}^{2}\right)^{-1} \sum_{i=1}^{N} \sum_{t=1}^{T} L_{11 i}^{-2}\left(\hat{e}_{i t-1} \Delta \hat{e}_{i t}-\widehat{\lambda}_{i}\right): \text { Panel Rho_stat } \\
Z_{t}^{w}=\left(\widetilde{s}_{N T}^{* 2} \sum_{i=1}^{N} \sum_{t=1}^{T} L_{11 i}^{-2} \hat{e}_{i t-1}^{* 2}\right)^{-1 / 2} \sum_{i=1}^{N} \sum_{t=1}^{T} L_{11 i}^{-2}\left(\hat{e}_{i t-1}^{*} \Delta \hat{e}_{i t}^{*}\right): \text { Panel Adf_stat } \\
Z_{p p}^{w}=\left(\widetilde{\sigma}^{2} \sum_{i=1}^{N} \sum_{t=1}^{T} L_{11 i}^{-2} \hat{e}_{i t-1}^{2}\right)^{-1 / 2} \sum_{i=1}^{N} \sum_{t=1}^{T} L_{11 i}^{-2}\left(\hat{e}_{i t-1} \Delta \hat{e}_{i t}-\widehat{\lambda}_{i}\right): \text { Panel PP_stat } \\
Z_{v}^{w}=\left(\sum_{i=1}^{N} \sum_{t=1}^{T} L_{11 i}^{-2} \hat{e}_{i t-1}^{2}\right)^{-1}: \text { Panel V_stat }
\end{gathered}
$$

For the Between statistics

$$
\begin{gathered}
Z_{\rho}^{B}=\sum_{i=1}^{N}\left(\sum_{t=1}^{T} \hat{e}_{i, t-1}^{2}\right)^{-1} \sum_{t=1}^{T}\left(\hat{e}_{i t-1} \Delta \hat{e}_{i t}-\widehat{\lambda}_{i}\right): \text { Group Rho_stat } \\
Z_{t}^{B}=\sum_{i=1}^{N}\left(\widehat{\sigma}_{i}^{2} \sum_{t=1}^{T} \hat{e}_{i, t-1}^{2}\right)^{-1} \sum_{t=1}^{T}\left(\left(\hat{e}_{i t-1} \Delta \hat{e}_{i t}-\widehat{\lambda}_{i}\right):\right. \text { Group Adf_stat } \\
Z_{p p}^{B}=\sum_{i=1}^{N}\left(\sum_{t=1}^{T} \hat{s}^{* 2} \hat{e}_{i t-1}^{* 2}\right)^{-1} \sum_{t=1}^{T}\left(\hat{e}_{i t-1}^{*} \Delta \hat{e}_{i t}^{*}\right): \text { Group PP_stat }
\end{gathered}
$$

with,

$\widehat{\lambda}=\frac{1}{T} \sum_{s=1}^{k_{i}}\left(1-\frac{s}{k_{i}+1}\right) \sum_{t=s+1}^{t} \widehat{\mu}_{i t} \widehat{\mu}_{i t-s}$ 
$\widehat{s}_{i}^{2}=\frac{1}{T} \sum_{t=s+1}^{t} \widehat{\mu}_{i t}^{2}, \widehat{\sigma}^{2}=s_{i}^{2}+2 \widehat{\lambda}_{i}$

$\widetilde{\sigma}_{i}=\widehat{s}_{i}^{2}+2 \widehat{\lambda}_{i}$,

$\widetilde{\sigma}_{N T}^{2} \frac{1}{T} \sum_{i=1}^{N} \widehat{L}_{11 i}^{-2} \widehat{\sigma}_{i}^{2}$

$\widehat{s}_{i}^{* 2}=\frac{1}{T} \sum_{t=s+1}^{t} \widehat{\mu}_{i t}^{* 2}, \widetilde{s}_{N T}^{* 2}=\frac{1}{T} \sum_{t=s+1}^{t} \widehat{s}_{i t}^{* 2}, \widehat{L}_{11 i}^{2} \sum_{t=1}^{T} \widehat{\eta}_{i t}^{2}+\frac{2}{T} \sum_{s=1}^{k_{i}}\left(1-\frac{s}{k_{i}+1}\right) \sum_{i=1}^{T} \widehat{\eta}_{i t} \widehat{\eta}_{i t-s}$ and where the residuals are extracted from the above regressions :

$\widehat{e}_{i t}=\widehat{\rho}_{i t-1}+\widehat{u}_{i t}$,

$\widehat{e}_{i t}=\widehat{\rho}_{i t-1}+\sum_{k=1}^{K_{i}} \widehat{\gamma}_{i k} \Delta \widehat{e}_{i t-k}+\widehat{u}_{i t}$,

$\Delta y_{i t}=\sum_{m=1}^{M} \widehat{b}_{m i} \Delta X_{m i t}+\widehat{\eta}_{i t}$

Note that in the above writings $L_{i}$ represents the $i^{\text {th }}$ component of the Cholesky decomposition of the residual Variance-Covariance matrix,$\widehat{\lambda}$ and $\tilde{\sigma}_{N T}^{2}$ are two parameters used to adjust the autocorrelation in the model, $\sigma_{i}$ and $\mathrm{s}_{i}^{2}$ are the contemporaneous and long-run individual variances.

Pedroni has shown that the asymptotic distribution of these seven statistics can be expressed as :

$$
\frac{\chi_{N T}-\mu \sqrt{N}}{\sqrt{v}} \rightarrow N(0,1)
$$

where $\chi_{N T}$ is the statistic under consideration among the seven proposed, $\mathrm{N}$ and $\mathrm{T}$ are the sample parameter values and $\mu$ and $\nu$ are parameters tabulated in Pedroni (1999).

In terms of power Pedroni (1997) showed that for values of T larger than 100, all the proposed seven statistics do fairly well and are quite stable. However for smaller samples (T inferior to 20) the Group ADF-Statistic (non-parametric) is the most powerful, followed by the Panel v-Statistic and the Panel rho-Statistic. For this reason, only the group ADF-statistic will be considered in our study for panel cointegration testing. The finite sample distribution for the seven statistics were tabulated by Pedroni (1997) via Monte Carlo simulations. The calculated 
test statistics must be larger (in absolute value) than the tabulated critical value to reject the null hypothesis of the absence of cointegration.

\section{The econometric investigation of the PPP for a panel of 73 developing and developed coun- tries}

\subsection{PPP, development level and geographic zone}

\subsubsection{Tests of the strong PPP}

In addition to the conventional ADF tests applied to individual series (cf. table 3 in the appendix), we have implemented the panel data unit-root test proposed by Im, Peseran and Shin (1997) to examine the integratedness degree of our series. Tests are carried out on two types of specifications: with constant and with constant and determinist trend ${ }^{8}$. The results of these panel data tests for the original and adjusted series of the two real exchange rate indicators are reported in the table below ${ }^{9}$ :

\footnotetext{
${ }^{8}$ It is important to note that the existence of a trend in the real exchange rate series is a violation of the traditional PPP form such as it has been defined by Cassel (1922). The results of these tests on adjusted data which do not integrate a trend are more adequate.

${ }^{9}$ The critical value is 1.65 . The null hypothesis of unit-root is rejected by data if the calculated statistic is larger than the $5 \%$ critical value.
} 
Table : Panel data unit-root tests (IPS, 1997)

\begin{tabular}{lccccc}
\hline \hline \multicolumn{5}{c}{ Unadjusted data } & \multicolumn{4}{c}{ Adjusted data } & N \\
& $\mathrm{C}$ & $\mathrm{C}+\mathrm{T}$ & $\mathrm{C}$ & $\mathrm{C}+\mathrm{T}$ \\
\hline Bfrica & -3.67 & -0.41 & -1.13 & 1.62 & 13 \\
Latin America & -1.37 & -0.74 & -1.37 & -0.74 & 16 \\
Asia & -1.87 & -1.32 & -1.51 & -0.77 & 9 \\
MENA & 1.26 & 2.04 & 2.10 & 0.68 & 6 \\
PECO & 1.43 & 2.32 & -1.63 & 1.33 & 12 \\
OECD & -3.30 & -0.83 & -3.30 & -0.83 & 20 \\
\hline \multicolumn{7}{c}{ Multilateral real exchange rate } \\
\hline Africa & -0.38 & -0.93 & 0.19 & -0.40 & 13 \\
Latin America & -3.15 & -3.16 & -3.06 & -2.76 & 19 \\
Asia & -1.51 & -0.77 & -2.34 & -0.27 & 9 \\
MENA & -0.24 & 1.56 & 0.57 & 0.35 & 6 \\
PECO & -1.25 & -3.69 & -3.45 & -3.18 & 22 \\
OECD & \multicolumn{7}{c}{} \\
\hline \hline
\end{tabular}

For Africa and for the two real exchange rate indicators, individual unitroot tests don't reject in most cases the null-hypothesis of non-stationarity, even though the sample small size does not permit to have information about the power of the tests (cf. table 3 in the appendix). For the first specification (with constant), individual tests reject the unit-root hypothesis for 5 countries out of 13, whatever the indicator of the real exchange rate is. The results of the panel data unit-root test confirm those of the individual tests and indicate that the hypothesis of real exchange rate stationarity cannot be accepted. Globally, the tests carried out on the adjusted series confirm the results obtained on the unadjusted data, except for the bilateral exchange rate and when we suppose a model with a constant. Indeed, tests reject the null-hypothesis of unit-root for the unadjusted series and accept it for the adjusted series.

Concerning Latin America, the individual tests results are very close to those of African countries in sofar as real exchange appears in most cases as a nonstationary variable. The hypothesis of non-stationarity is rejected in only 7 countries out of 19 for the multilateral exchange rate, and in 3 countries out of 16 for the bilateral real exchange rate. On the other hand, panel data tests confirm the non-stationarity hypothesis when working with the bilateral real 
exchange rate, and reject it for the effective exchange rate. The results are not modified by the type of data used.

For Asia, the results of the panel data unit-root test depend on the type of data considered. Indeed, for the first specification (with constant) and using unadjusted data, we conclude that the bilateral real exchange rate is stationary whereas the multilateral exchange rate is not. We find an opposite result for the adjusted data. For the second specification (with constant and trend) tests indicate that bilateral and multilateral real exchange rates are integrated of order 1 whether we consider the unadjusted or adjusted data. Tests on individual data are not in accordance with the panel data unit-root test since for the two indicators, the hypothesis of non-stationarity is strongly accepted.

Similar results are found for the PECO, since individual tests reveal that for the whole group of countries the hypothesis of non-stationarity of the real exchange rate is accepted. The panel data unit-root test leads to the same conclusion and support the non-stationarity of the real exchange rate at a $5 \%$ level of significance.

The individual unit-root test results confirm the non-stationarity of the bilateral real exchange rate and of the effective exchange rate for the 6 MENA countries. However, the panel data unit-root tests show that for the model with constant, the bilateral exchange rate is integrated of order one for the unadjusted data and stationary for the adjusted series. We get opposite results for the model with a trend. However, we obtain more robust results for the multilateral exchange rate. Indeed, independently of the type of data used and whatever the specification chosen is, tests clearly indicate that the real exchange rate is integrated of order 1 .

For developed countries, results reveal that for the unadjusted data the effective exchange rate is stationary, whereas the bilateral exchange rate is integrated. However, applied to adjusted data, the tests confirm the stationarity of the real exchange rate for both indicators. The panel data unit-root tests contradict individual tests and indicate that generally the real exchange rate is stationary. Consequently, it seems that individual tests suffer from low power 
and are unable to reject the null hypothesis of non-stationarity in small samples. These empirical elements in favour of the PPP in developed countries can be explained by low transaction costs (distance), the absence of tariff barriers and the relative stability of the adopted trade policies. These results are identical to those found in the previous studies of literature, which generally confirm the PPP for developed economies.

To conclude, the panel data unit-root tests implemented in this sub-section generally confirm the PPP for developed countries. On the contrary, for developing countries the strong PPP is not verified. This result indicates on the one hand that the price convergence process between developing countries and their trading partners is not yet finished, and on the other, that certain sources of nuisance exist which prevent a full nominal exchange rate adaptation to price variations. Taylor (1998) evoked transaction costs as a possible source of nuisance. Patel (1990) noticed that differences in the construction of price indices between countries could also lead to the empirical rejection of the strong PPP. Finally, Park (1991) considered that the productivity differential could induce a non-unitary cointegration coefficient between the nominal exchange rate and the price ratio. However, the rejection of the strong PPP does not necessarily imply that the "weak" form is not verified. Indeed, it is important to underline that panel data unit-root tests impose a unitary and homogeneous ${ }^{10}$ cointegration coefficient between the nominal exchange rate and the price ratio. But many authors showed that, although an equilibrium relationship can exist between these two variables, for a more general interpretation of the PPP (weak PPP), it is not necessary that the coefficient of cointegration should be equal to one. Consequently, in the next sub-section we will pursue the analysis to examine whether the weak PPP holds or not in developing countries.

\footnotetext{
${ }^{10}$ Actually panel data unit-root tests assume an average relationship for the whole sample with a unitary cointegration coefficient.
} 


\subsubsection{Tests of the PPP "weak" form}

The test of the weak PPP consists in testing the existence of a cointegration relation between the nominal exchange rate and the price ratio. The results of the test of Pedroni's cointegration (Group-adf-statistics are reported in table $2)^{11}$.

Table 2 : Panel data cointegration tests (Pedroni, 1997, 1999)

\begin{tabular}{ccccccc}
\hline \hline & Africa & Latin America & Asia & MENA & PECO & OECD \\
Group-adf-stat & -1.37 & -1.57 & 0.61 & -3.21 & -1.203 & -4.38 \\
\hline \hline
\end{tabular}

Let us begin by noticing that, for the developed and MENA countries, the weak PPP is verified ${ }^{12}$. Furthermore, tests on individual data (cf. table 5 in the appendix) show that for the majority of countries, the hypothesis of cointegration cannot be rejected. This last result does not contradict the strong PPP for that, but permits to account for the ambiguous results obtained by the panel data unit-root tests.

However, the panel data cointegration tests indicate that the weak PPP is rejected by data for Africa, Latin America, Asia and the PECO, which means that in many developing countries, the PPP cannot be used as a benchmark to determine the long-run evolution of the real exchange rate.

On the basis of the economic specificities of developing countries we can evoke the following factors to justify these empirical results:

- Obstacles in international exchanges are likely to influence asymmetrically relative prices by disrupting the spatial arbitrage. In fact, even though economic liberalization seems to be the general tendency in most developing countries, there still exits tariff and non-tariff barriers in some countries which limit free trade.

\footnotetext{
${ }^{11}$ The $5 \%$ critical value is 1.65 . The null hypothesis of absence of a cointegration relationship is rejected if the calculated statistic is larger than the critical value.

${ }^{12}$ This indicates the coherency between the results of this section and those of the previous one, obtained with a different econometric panel data method.
} 
- Inflationary anticipations exercise an upward pressure on domestic prices with regard to foreign prices. In fact, most developing countries suffer from a price instability often explained by inadequate monetary and budgetary policies.

- Long-run capital movements can also provoke PPP deviations. Developing countries can also have benefited from important capital flows in terms of foreign direct investments. These capital flows often entail a long-run real exchange rate appreciation.

- Interventions on the exchange market can influence the value of the currency. Some countries are indeed brought to intervene on the exchange market to face fluctuations in exchange rates and hence strengthen their export competitiveness.

- The modifications of relative prices reflecting structural changes in the economy can induce exchange rate deviations with regard to the PPP. In fact in the early 80s, most developing countries began important structural programs to restructure their economy. These efforts of reorganization permitted to liberalize prices while strengthening the export sector competitiveness. Productivity gains obtained in the tradable goods sector entailed a decrease of their relative price and hence a continuous real exchange rate appreciation (Balassa-Samuelson effect).

The first battery of tests implemented on the basis of a geographic decomposition and of the development level showed that for most developing countries, the PPP does not seem relevant to characterize the real exchange rate evolution (with the exception of the MENA countries for the PPP "weak" form). The economic specificities of the various geographic zones seem to play an important role in the determination of the long-run real exchange rate behavior. We investigate this possibility in the next sub-section. 


\subsection{PPP, exchange rate regimes and inflation}

As we have just seen it before,the level of development is not a suitable criterion to assess the PPP relevance to characterize the long-run evolution of the real exchange rate. Our aim in this sub-section is to identify other economic specificities that could influence the real exchange rate behavior. The basic idea is that the PPP tends to be more easily accepted in countries with high inflation than in countries with low or medium ones. We also recognize a certain role to the nature of the exchange rate regime in the determination of the real exchange rate behavior. It is however important to notice that until now we do not have enough empirical works at our disposal to confirm these ideas. The rarity of studies can be explained by the low power of conventional econometric methods in small samples. But the recent development of panel data econometric techniques now permit to re-examine this question and investigate whether these theoretical intuitions are empirically verified.

We now proceed to a decomposition of our sample of countries according to the relative flexibility of the exchange rate regime and the inflation level. We begin by examining the relationship between the exchange rate flexibility and PPP and we then come back on the effect of inflation.

\subsubsection{PPP and exchange rate regimes}

Countries are classified in two subgroups: those with a fixed exchange rate regime and those with a floating exchange rate one. The nature and stability ${ }^{13}$ of the exchange rate regime during the period of study, which goes from 1970 to 1983 for the fixed exchange rate regime and from 1990 to 1998 for the floating exchange rate one, represent the classification criteria of the various countries of our sample. Only the countries for which the exchange rate regime is stable during the period of study are included, the others are excluded from the sample, which reduces the number of countries to 16 for the fixed exchange rate regime and to 35 for the flexible one.

\footnotetext{
${ }^{13}$ We present in the appendix the classification method of countries according to the exchange rate regime.
} 
The econometric method used in this sub-section rests upon Pedroni's panel data cointegration test (cf. Pedroni 1997, 1999, 2000) and also on the unitary cointegration coefficient tests recently developed by Pedroni. Indeed, Pedroni (2001) made an extension of conventional panel data unit-root tests to test constraints on the estimated cointegration coefficients. The advantage of this test in comparison to the unit-root tests previously used is that it is based on the Fully Modified ordinary least squares (Fmols), which corrects possible nuisances in small sized samples. Pedroni (2001) showed that this method lead to more robust results when working with small sized samples (as it is precisely the case here $)^{14}$ than the Ordinary Least square (OLS) method. Besides, these simulations indicate that the unit-root tests based on the OLS are biased in small samples and wrongly too often reject the null hypothesis. The results of tests are reported in table 3 :

Table 3 : PPP and exchange rate regime

\begin{tabular}{lcc}
\hline \hline & Fixed regime & Flexible regime \\
\hline & strong PPP \\
\hline Constant & 6.98 & -5.03 \\
Constant + trend & -1.23 & 7.05 \\
\hline \multicolumn{3}{c}{ weak PPP } \\
\hline Group-ADF-stat & -1.87 & -1.89 \\
Number of observations & 224 & 315 \\
\hline \hline
\end{tabular}

Panel data cointegration tests show that the strong PPP is empirically rejected for the two exchange rate regimes. We have also implemented panel data unit-root tests and found that for the floating exchange rate regime, the strong PPP holds independently of the adopted specifications (constant and constant and trend). However, for the fixed exchange rate regime the strong PPP is rejected for the first specification (without trend) and accepted for the second one (with trend). Once again these results confirm the superiority of Pedroni's tests (2001) with regard to the previous panel data unit-root tests. On the contrary, the panel data cointegration tests confirm the weak PPP for the two exchange

\footnotetext{
${ }^{14}$ The superiority of the Fmols method has been confirmed by Philipps and Hansen (1990) and Philipps (1995) on individual data.
} 
rate regimes ${ }^{15}$.

Oh (1996) found different results and showed that in developing countries, the PPP "strong is accepted for the fixed exchange rate regime period whereas it is rejected for the flexible one. On the other hand, in developed countries, panel data unit-root tests accept the non-stationarity of the real exchange rate for the fixed exchange rate regime period and reject it for the flexible one. It is however important to notice that we do not proceed in the same way to distinguish the various exchange rate regimes. Indeed, Oh (1996) used a temporal decomposition: from 1960 to 1972, the exchange rate regime is supposed to be flexible, and from 1973 to 1989, it is supposed to be fixed. However, in our analysis, we tried to take a classification with regard to a composite index into account, which allows to distinguish the various exchange rate regimes on the basis of the relative volatility of the nominal exchange rate and of the exchange reserves. This way of proceeding permits to take what is effectively the actual exchange rate regime into account and not what is officially announced. Furthermore, to limit the nuisances which can cause changes of exchange rate regimes with time, we also took the exchange rate regime stability into account. The econometric method used here is also different because instead of carrying out unit-root tests, we directly tested whether the cointegration coefficient between the prices of the economy and its trading partner, expressed in the same currency, is equal or not to 1 .

Hence it clearly emerges from our econometric investigations that the PPP validity does not depend on the exchange rate regime. This is a useful and significant result as until today we did not have a clear answer to the relationships between the nature of the exchange rate regime and the stochastic properties of the real exchange rate, on the basis of the previous works of literature. Indeed,according to Gulli and Kaminski (1991) the real exchange rate behavior depends on the period of study and on the historic events rather than on the current exchange rate regime. In other words, it is the nature of macroeconomic

\footnotetext{
${ }^{15}$ The cointegration tests consist in testing the existence of a long-run relationship between domestic and foreign prices expressed in the same currency.
} 
shocks which affect economy, as well as the stability of the exchange rate regime with time which determine the long-run behavior of the exchange rate. Besides, several empirical studied showed that between the early 80 s and the early 90 s, the exchange rate regimes adopted, both by developing and developed countries were not stable $^{16}$. Countries had the concern to elaborate the best adapted exchange rate policy to an economic environment characterized with an increased openness on the outside. These adaptation led economies to frequently change their exchange rate policies. It is only from the 90 s that we notice a relative stability of exchange rate regimes in several countries. We therefore think that the higher exchange rate volatility which characterized the posterior "Breton Woods" period can be explained by the exchange rate regime instability rather than by its flexibility. In fact, whether the exchange rate regime is flexible or fixed, there always exists a combination of prices and of the nominal exchange rate which assures the long-run real exchange rate stability. In the fixed exchange rate regime with macroeconomic shocks, prices adjust themselves in the long-run to maintain the real exchange rate stability. On the contrary, in the floating exchange rate regime, both prices and nominal exchange rate adjust themselves and a combination of the two can exist to assure the PPP. Finally, it seems that it is more the low power of conventional econometric methods rather than the exchange rate regime instability characterizing the periods of study that accounts for the empirical rejection of the PPP obtained in the previous studies of literature.

\subsubsection{PPP and inflation}

We now decompose our sample of countries according to the inflation level. The countries in which the average level of inflation does not exceed $10 \%$ are classified as countries with low inflation, the others are classified as countries with high inflation. Here again the stability of the inflation level during the

\footnotetext{
${ }^{16}$ Levy-Yeyati and Sturzenzgger (1999) classified the exchange regimes in a group of developing and developed countries according to an index of exchange volatility. Their analysis reveals that most countries had to change several time of exchange regime during the period of study.
} 
period of study is taken into account. We exclude from our sample the countries in which the inflation rate has varied frequently during the period. In other words, the countries which cannot be classified in one of the two groups for the whole period of study are excluded from the analysis.

\begin{tabular}{|c|c|c|}
\hline & High inflation & Low inflation \\
\hline \multicolumn{3}{|c|}{ PPP "strong form" } \\
\hline Constant & -1.51 & 2.60 \\
\hline Constant and trend & -1.72 & -4.31 \\
\hline \multicolumn{3}{|c|}{ PPP "weak form" } \\
\hline Group-ADF-stat & 5.59 & 1.79 \\
\hline Number of observations & 1190 & 665 \\
\hline
\end{tabular}

The results of the panel data unit-root tests reveal that the strong PPP is more often accepted in countries with high inflation than in countries with low one. However, cointegration tests indicate that the weak PPP is as often accepted in countries with high inflation as in countries with low one ${ }^{17}$. These results are compatible with those of Holmes (2000) who found for a sample of African countries that the strong PPP is more easily accepted in countries with high inflation than for countries with low one. Besides, our results are in accordance with the theoretical predictions according to which the PPP is more easily accepted in countries with high inflation. Indeed, in high inflation countries nominal shocks account for most part of the real exchange rate fluctuations, and consequently PPP deviations can only be temporary. Furthermore, an inflationary environment favors spatial and temporal arbitrage, which strengthens the convergence of prices between countries.

\section{Conclusion}

The attempts to test for the PPP pose numerous methodological problems. If we consider the PPP basic versions, the real exchange rate should be constant. That is why due to the important fluctuations of real parities observed,

\footnotetext{
${ }^{17}$ Holmes (2001), Mahdavi and Zho (1994), Mc Nown and Wallace (1989) also confirmed that the PPA holds in countries with high inflation.
} 
the defenders of the PPP consider that this theory is only valid in the long-run, because of very slow adjustment mechanisms. However, even at this horizon few econometric studies found evidence in favor of the PPP. In particular, the most recent works using time series econometric techniques for developed countries, generally stressed the real exchange rate non-stationarity, hence providing empirical evidence against the PPP. The aim of this paper was to investigate whether the PPP concept could serve as a benchmark to determine the real exchange rate evolution in a large sample of developed and developing countries. The recent panel data integration and cointegration techniques have been carried out to remedy the low power of conventional time series econometric methods in small samples.

Our investigations indicate that the PPP strong form is verified for OECD and MENA countries. However in Africa, Asia, Latin America and the PECO, PPP does not seem relevant to characterize the long-run behavior of the real exchange rate. A widening of our analysis field shows on the one hand that the nature of the exchange rate regime doesn't condition the validity of the PPP and on the other that the PPP is accepted more easily in countries with high inflation than with low one.

Our study puts in evidence the absence of an equilibrium relationship between national prices, foreign prices and the exchange rate for developing countries, hence confirming that the PPP theory is empirically rejected. This result also confirms that PPP deviations are permanent.

Apart from the problems of trade obstacles and price rigidity which characterize most developing economies, the productivity shocks can also explain the persistent deviations of exchange rates with regard to their equilibrium level defined with the PPP. According to the Balassa-Samuelson theory (1964), the tradable sector productivity increase entails a long-run appreciation of the real exchange rate and hence persistent PPP deviations. Besides the BalassaSamuelson effect, other macroeconomic variables such as the terms of trade, capital movements, public spending can also influence the real exchange rate equilibrium level. 


\section{References}

[1] Balassa B. (1964), "The Purchasing Power Parity Doctrine : A Reappraisal," Journal of political Economy, Vol. 72, pp 584-96.

[2] Breuer J. B, (1994) "An Assessment of the Evidence on PPP, " in J. Williamson (ed.) Estimating Equilibrium Exchange Rate, Washington, D. C. : Institute for International Economics.

[3] Canzoneri M., Cumby R., Diba B. (1996), "Relative labor productivity and the real exchange rate in the long run : evidence for a panel of OECD countries," Journal of International Economics; Vol. 47, pp 245-266.

[4] Dickey D. and W. Fuller (1979), "Distribution of the Estimators for Autoregressive Time Series with Unit Root," Journal of the American Statistical Association, Vol. 74, pp 427-81.

[5] Froot K. and K. Rogoff (1995), "Perspectives on PPP and the Long-Run Real Exchange Rate," in G. Grossman and K. Rogoff (ed.), Handbook of International Economics, Vol. 3, Amsterdam : North Holland Press.

[6] Grilli V. and Kaminsky G. (1991), "Nominal Exchange Rate and Real Exchange Rate: Evidence from the Unites States and Great Britain 18851986," Journal of Monetary Economics, Vol. 27, pp 192-212.

[7] Holmes J (2000), "Does PPP hold in African Less Developed Countries ? Evidence from a Panel Data and Root Test," Journal of African Economies, Vol $9, \mathrm{~N}^{\circ} 1$, pp 63-78.

[8] Im, K. Pesaran, H., and Shin, Y. (1997), "Testing for Unit Roots in Heterogeneous Panels," Manuscript, University of Cambridge.

[9] Levin and Lin (1993), Unit Root Tests in Panel Data, Asymptotic and Finite Sample Properties, U.C. San Diego Working paper. 
[10] Mussa M. (1986), "Nominal Exchange Rate Regimes and the Behavioral of Real Exchange Rates: Evidence and Implications," Carnegie Rochester Conference Series on Public Policy, Vol. 27, pp 117-214.

[11] Nagayasu J. (1998), "Does the Long-Run PPP Hypothesis Hold for Africa?: Evidence from Panel Co-Integration Study," Working Paper 98/123, International Monetary Fund, Washington, D. C.

[12] Obstfeld M. and A. Taylor (1996), International Capital Market Integration over The Long Lun: The Great Depression as a Watershed, U. C. Berkeley.

[13] O'Connel (1998), "The Overvaluation of Purchasing Power Parity," Journal of International Economics, Vol. 44, pp 1-19. (forthcoming).

[14] Oh K. (1996), "Purchasing Power Parity and Unit Root Tests using Panel Data," Journal of International Money and Finance ( to be published).

[15] Patel J. (1990), "Purchasing Power Parity as as Long-Run Relation," Journal of Applied Econometrics, Vol. 5, pp 367-79.

[16] Pedroni P.(1995), "Panel Cointegration : Asymptotic and Finite Sample Properties of Pooled Time Series Tests with an Application to the PPP Hypothesis," Indiana University Working Paper in Economics, n55-013.

[17] Pedroni, P. (1997), "Panel Cointegration : Asymptotic and Finite Sample Properties of Pooled Time Series Tests with an Application to the PPP Hypothesis : New Results", Indiana University Working Paper in Economics, April.

[18] Pedroni P. (1999), "Critical Values for Cointegration Tests in Heterogeneous Panels with Multiple Regressors," Oxford Bulletin of Economy and Statistics, pp 653-670.

[19] Pedroni P. (2000), "PPP Tests in Cointegrated Panels," Indiana University Working Papers. 
[20] Pedroni P. (2001), "Panel Cointegration Asymptotic and Finite Sample Properties of Pooled Time Series Tests with an Application to the PPP Hypothesis, " Department of Economics, Indiana University Working Papers.

[21] Phillips, P. and Ouliaris (1988), "Asymptotic Properties of Residual Based Tests for Cointegration," Econometrica, Vol. 58, pp 165-193.

[22] Quah D. (1994), "Exploiting Cross-Section Variation for Unit Root Inference in Dynamic Data," Economics Letters, Vol. 44, pp 9-19.

[23] Rogoff K. (1996), "The Purchasing Power Parity Puzzle," Journal of Economic Literature, Vol. 34, pp 647-668.

[24] Samuelson, P.A. (1964), "Theoretical Notes on Trade Problems," Review of Economics and Statistics, vol 46, pp 335-46.

[25] Taylor A. (1996), "International Capital Mobility in History : Purchasing Power Parity in the Long Run," North-western University Working Papers.

[26] Taylor, M. P. and L. Sarno (1998), "The Behavioral of Real Exchange Rate During the Post-Bretton Woods Period," Journal of International Economics, Vol. 46, pp 281-312.

[27] Wei, S.J. and Parsley D. (1995), "Purchasing power dis-parity during the floating rate period : exchange rate volatility, trade barriers, and other culprits", Manuscript, Harvard University. 


\section{Appendix}

\section{$\underline{\text { Appendix } 1 \text { : Complete econometric test results }}$}

\section{PPP, development level and geographic zone}

\section{A) Tests of the strong PPP}

Table 1 : Stationarity tests of the real exchange rate

\begin{tabular}{|c|c|c|c|c|}
\hline & \multicolumn{2}{|c|}{ Bilateral rate $^{1}$} & Multilateral rate ${ }^{2}$ & \multirow[b]{2}{*}{$\mathrm{C}+\mathrm{T}$} \\
\hline & C & $\mathbf{C}+\mathrm{T}$ & C & \\
\hline AFRICA & \multicolumn{3}{|c|}{ Individual tests ${ }^{3}$} & \\
\hline Botswana & $-2.34 \quad(0)$ & $-5.90^{* * *}(3)$ & $-0.95 \quad(0)$ & $-2.23 \quad(0)$ \\
\hline Burundi & $-3.05^{\star *}(0)$ & $-2.50 \quad(0)$ & $-3.11^{* *}(0)$ & $-2.50 \quad(0)$ \\
\hline Gambia & $-4.04^{* * *}(3)$ & $-1.22 \quad(0)$ & $-4.28^{* * *}(3)$ & $-7.02^{* * *}(3)$ \\
\hline Ghana & $-1.08 \quad(0)$ & $-1.98 \quad(0)$ & $-1.01 \quad(0)$ & $-2.01 \quad(0)$ \\
\hline Kenya & $0.02 \quad(0)$ & $-1.90 \quad(0)$ & $-0.15 \quad(0)$ & -2.05 \\
\hline Malawi & $-4.00^{* * *}(3)$ & $-2.8 \quad(3)$ & -2.24 & $-2.79 \quad(2)$ \\
\hline Niger & $-1.55 \quad(4)$ & $-4.40^{* * *}(2)$ & $-5.09^{* * *}(2)$ & $-3.05 \quad(2)$ \\
\hline Uganda & $-1.51 \quad(0)$ & $-3.89^{* *}(4)$ & $-1.49 \quad(0)$ & $-4.03^{* *}(4)$ \\
\hline RSA & $-1.37 \quad(0)$ & $-1.23 \quad(0)$ & $-1.46 \quad(0)$ & $-1.27 \quad(0)$ \\
\hline Sierra Leone & $-3.58^{* * *}(3)$ & -2.91 & $-1.76 \quad(0)$ & $-3.37^{* *}(3)$ \\
\hline Tanzania & $-2.26 \quad(0)$ & $-2.33 \quad(0)$ & $-2.25 \quad(0)$ & $-2.33 \quad(0)$ \\
\hline Zimbabwe & $-4.98^{\star * *}(1)$ & $-5.75^{\star * *}(4)$ & $-3.04^{* *}(4)$ & -2.32 \\
\hline \multirow[t]{5}{*}{ Zambia } & $-1.43 \quad(0)$ & $-1.28(0)$ & $-3.33^{* *}(4)$ & -2.08 \\
\hline & \multicolumn{4}{|c|}{ Panel data unit-root test, Pedroni $(1999,1999,2000)$} \\
\hline & \multicolumn{3}{|c|}{$\begin{array}{l}\text { Unadjusted Data } \\
-0.41\end{array}$} & \\
\hline & \multicolumn{3}{|c|}{ Adjusted data ${ }^{4}$} & -0.93 \\
\hline & -1.13 & 1.62 & 0.19 & -0.40 \\
\hline LATIN AMERICA & \multicolumn{3}{|c|}{ Individual tests I } & \\
\hline Argentina & $-1.97(0)$ & \multirow{3}{*}{$\begin{array}{l}-2.24(0) \\
-2.26(0)\end{array}$} & $-1.84(5)$ & $-2.13(5)$ \\
\hline Bolivia & $-2.22(0)$ & & $-1.97(0)$ & $-1.81(0)$ \\
\hline Brazil & & & $-1.40(0)$ & $-2.22(0)$ \\
\hline Chile & $-2.11(0)$ & $-1.70(0)$ & $-2.14(0)$ & $-3.11^{*}(1)$ \\
\hline Colombia & $-2.69 *(5)$ & $-3.14(5)$ & $-2.80^{*}(5)$ & $-3.33^{*}(5)$ \\
\hline Costa Rica & $-2.22(0)$ & $-2.15(0)$ & $-3.27^{* *}(0)$ & $-3.18^{*}(0)$ \\
\hline El Salvador & & & $0.02(3)$ & $-2.03(3)$ \\
\hline Ecuador & $-3.07^{* *}(2)$ & $-2.98(2)$ & $-0.96(0)$ & $-1.30(0)$ \\
\hline Guatemala & $-1.87(5)$ & $-2.74(3)$ & $-2.93^{* *}(0)$ & $-3.51(1)$ \\
\hline Guyana & $-0.46 \quad(2)$ & $-2.24(2)$ & $-0.66(3)$ & $-4.62^{\star * *}(0)$ \\
\hline Honduras & $-2.39(2)$ & $-2.31(0)$ & $-2.38(3)$ & $-2.87(3)$ \\
\hline Jamaica & & & $-2.78(1)$ & $-3.19^{*}(1)$ \\
\hline Mexico & $-0.54 \quad(0)$ & $-2.78(0)$ & $-3.68^{* * *}(1)$ & $-3.78^{*}(1)$ \\
\hline Nicaragua & $-1.75(0)$ & $-2.25(0)$ & $-1.71(1)$ & $-1.88(2)$ \\
\hline Panama & $-1.18(0)$ & $-1.06(0)$ & $-3.09^{* *}(5)$ & $-3.24^{*}(5)$ \\
\hline Paraguay & $-2.05 \quad(5)$ & $-2.24(0)$ & $-1.93(5)$ & $-1.60(5)$ \\
\hline Peru & $-0.45 \quad(0)$ & $-1.58(0)$ & $-2.01(0)$ & $-2.16(0)$ \\
\hline Uruguay & $-0.99(0)$ & $-2.10(0)$ & $-2.65^{*}(0)$ & $-3.26^{*}(2)$ \\
\hline Venezuela & $-3.30^{* *}(0)$ & $-3.15(0)$ & $-2.7^{*}(0)$ & $-2.51(3)$ \\
\hline \multicolumn{5}{|c|}{ Panel data test ${ }^{5}$} \\
\hline \multicolumn{5}{|c|}{ Unadjusted Data } \\
\hline & -1.37 & -0.74 & -3.15 & -3.16 \\
\hline \multicolumn{5}{|c|}{ Adjusted data } \\
\hline & -1.37 & -0.74 & -3.03 & -2.76 \\
\hline
\end{tabular}

\footnotetext{
${ }^{1}$ It is the bilateral real exchange rate with respect to the United States and calculated on the basis of the consumption price index..

${ }^{2}$ It is the multilateral exchange rate calculated with regard to the main trading partners.

${ }^{3}$ It is the conventional ADF unit-root test. The number of lags is in brackets. *,

$* *$, and $* * *$ indicate the real exchange rate stationarity respectively at the $10 \%, 5$

$\%$ and $1 \%$ levels.

${ }^{4}$ The data are corrected from the intra-group correlation..

${ }^{5}$ The critical value is 1.65 .
} 


\begin{tabular}{|c|c|c|c|c|}
\hline ASIA & \multicolumn{4}{|c|}{ Individual tests I } \\
\hline Korea & $-1.88(1)$ & $-3.14(1)$ & $-1.52(0)$ & $-1.61(0)$ \\
\hline Hong-Kong & $-1.09(1)$ & $-0.48(1)$ & $-0.80(1)$ & $-3.44^{*}(3)$ \\
\hline India & $.97(1)$ & $-4.52^{* * *}(4)$ & $-1.09(3)$ & $-2.77(4)$ \\
\hline Indonesia & $-0.87(0)$ & $-1.76(1)$ & $-0.59(0)$ & $-0.81(0)$ \\
\hline Japan & $-0.75(4)$ & $-2.98(1)$ & $-0.44(4)$ & $-1.49(0)$ \\
\hline Malaysia & $-1.54(1)$ & $-2.83(1)$ & $-1.57(0)$ & $-1.70(0)$ \\
\hline The Philippines & $-2.05(0)$ & $-2.61(0)$ & $-1.23(2)$ & $-3.60 *(1)$ \\
\hline Singapore & $-1.41(3)$ & $-2.10(1)$ & $-3.33^{* *}(0)$ & $-2.85(0)$ \\
\hline Thailand & $-2.13(3)$ & $-2.17(0)$ & $-0.65(0)$ & $-3.06(0)$ \\
\hline & & Panel data & & \\
\hline & & Unadjus & Data & \\
\hline & -1.87 & $\begin{array}{l}-1.32 \\
\text { Adjusted }\end{array}$ & ta & -0.77 \\
\hline & -1.51 & -0.77 & -2.34 & -0.87 \\
\hline MENA & Individual tests & & & \\
\hline Algeria & $-1.07(0)$ & $-1.66(0)$ & $-1.50(3)$ & $-1.19(3)$ \\
\hline Egypt & $-1.98(1)$ & $-2.62(1)$ & $-1.18(1)$ & $-2.44(1)$ \\
\hline Jordan & $-0.77(0)$ & $-1.13(0)$ & $-1.65(0)$ & $-0.59(0)$ \\
\hline Morocco & $0.59(0)$ & $-0.69(0)$ & $-2.58(1)$ & $-3.17(1)$ \\
\hline Tunisia & $-0.45(0)$ & $-1.56(0)$ & $-1.17(0)$ & $-1.75(4)$ \\
\hline Turkey & $-1.73(0)$ & $-1.73(0)$ & $-1.68(0)$ & $-1.90(0)$ \\
\hline & & Panel daté & & \\
\hline & & Unadjus & Data & \\
\hline & 1.86 & $\begin{array}{l}2.04 \\
\text { Adjuste }\end{array}$ & ata $^{-0.24}$ & 1.56 \\
\hline & 2.10 & 0.68 & 0.57 & 0.35 \\
\hline OECD & & & idual tests & \\
\hline Australia & $-2.21 \quad(0)$ & $-2.59(1)$ & $-2.40 \quad(1)$ & $-3.09 \quad(4)$ \\
\hline Austria & $-2.68^{*}(1)$ & $-1.08(3)$ & -0.64 & $-3.51^{* *}(1)$ \\
\hline Belgium & $-0.38 \quad(0)$ & $-2.30(4)$ & -2.47 & $-3.67^{* *}(0)$ \\
\hline Canada & $-0.86(0)$ & $-2.74(4)$ & -1.73 & $-2.85 \quad(1)$ \\
\hline Denmark & $-3.13^{* *}(1)$ & $-1.25(0)$ & $-2.08 \quad(0)$ & -2.56 \\
\hline Spain & -1.91 (0) & $-2.78(1)$ & -1.59 & -1.82 \\
\hline Unites States & & & $-2.75^{*}(1)$ & $-2.67 \quad(1)$ \\
\hline Finland & $-1.68(0)$ & $-2.72(4)$ & $-2.71^{*}(1)$ & -2.75 \\
\hline France & $-2.35(0)$ & -2.60 (1) & $-2.34(0)$ & -1.96 \\
\hline Greece & $-1.38(0)$ & $-2.70(1)$ & $-3.34^{* *}(1)$ & $-3.29 * \quad(1)$ \\
\hline Iceland & $-2.94^{*}(1)$ & $-1.50(8)$ & -1.04 (0) & $-1.41 \quad(0)$ \\
\hline Ireland & $-2.65^{\star}(1)$ & $-2.86(1)$ & -0.35 & $-3.03 \quad(4)$ \\
\hline Italy & $-1.94(0)$ & $-2.02(2)$ & $-3.13^{* *}(1)$ & $-4.84^{\star * *}(3)$ \\
\hline Japan & & & -1.37 & $-3.39 *$ \\
\hline Luxemburg & $-2.95^{\star \star}(1)$ & $-1.48 \quad(0)$ & -2.27 & $\begin{array}{ll}-2.09 & (0)\end{array}$ \\
\hline N. Zealand & $-3.24^{* *}(1)$ & $-3.47^{*}(4)$ & $-3.76^{* *}(2)$ & $-4.05^{* *}(1)$ \\
\hline Holland & $-1.42(0)$ & $-2.94 \quad(1)$ & -1.43 & -2.87 \\
\hline Norway & -2.02 & $-3.06 \quad(4)$ & $-2.74^{*}(0)$ & $-2.95 \quad$ (1) \\
\hline Portugal & -2.02 (1) & -2.33 (1) & -1.79 & -1.81 \\
\hline United Kingdom & $-2.84^{*}(1)$ & $-1.34 \quad(0)$ & $-1.62 \quad(1)$ & $-1.51 \quad$ (1) \\
\hline Sweden & $-3.36^{\star *}(4)$ & $-4.28^{\star \star \star}(2)$ & -0.69 & $-5.10^{\star \star *}(2)$ \\
\hline Switzerland & -1.26 (2) & $-2.40 \quad(1)$ & -0.27 & $-1.60 \quad(4)$ \\
\hline & & Panel data $t$ & & \\
\hline & & Unadju & d Data & \\
\hline & -3.30 & -0.83 & -1.25 & -3.69 \\
\hline & & Adjuste & & \\
\hline & -3.30 & -0.83 & -3.45 & -3.18 \\
\hline PECO & & Individual $t$ & & \\
\hline Bulgaria & -0.38 & -2.56 & & \\
\hline Croatia & -0.61 & -3.59 & & \\
\hline Czech Republic & -0.77 & -2.94 & & \\
\hline Estonia & 0.95 & -2.94 & & \\
\hline Hungary & -1.49 & -1.90 & & \\
\hline Latvia & -2.11 & -2.04 & & \\
\hline Lithuania & -1.32 & -2.27 & & \\
\hline Poland & -1.32 & -1.71 & & \\
\hline Romania & -1.97 & -1.11 & & \\
\hline Russia & -1.85 & -1.27 & & \\
\hline Slovakia & -1.44 & -1.87 & & \\
\hline Slovenia & -1.52 & -1.85 & & \\
\hline & & Panel data $t$ & & \\
\hline & & Unadjuste & ata & \\
\hline & -1.43 & 2.32 & & \\
\hline & & Adjusted da & & \\
\hline & -1.63 & 1.33 & & \\
\hline
\end{tabular}




\section{B) Tests of the weak PPP}

Table 2 : Panel data unit-root test

\begin{tabular}{|c|c|c|c|c|}
\hline \multirow[b]{2}{*}{ Country } & \multicolumn{2}{|c|}{ Adjusted data } & \multicolumn{2}{|c|}{ Unadjusted Data } \\
\hline & Constant & Constant + trend & Constant & Constant + trend \\
\hline \multicolumn{5}{|c|}{ Nominal exchange rate } \\
\hline Africa & -0.18 & 0.68 & -0.18 & 0.68 \\
\hline Latin America & 0.19 & 1.14 & 0.19 & 1.14 \\
\hline Asia & 3.19 & 0.45 & 1.1 & 0.12 \\
\hline Mena & 5.71 & 0.64 & 1.1 & 0.71 \\
\hline $\begin{array}{l}\text { PECO } \\
\text { OECD }\end{array}$ & $\begin{array}{c}0.34 \\
-0.17\end{array}$ & $\begin{array}{l}1.76 \\
0.81\end{array}$ & $\begin{array}{c}0.54 \\
-0.17\end{array}$ & $\begin{array}{l}0.86 \\
0.81\end{array}$ \\
\hline \multicolumn{5}{|c|}{ Price ratio } \\
\hline Africa & 0.59 & 5.14 & 0.53 & 3.81 \\
\hline Latin America & 3.34 & 5.49 & 0.86 & -0.98 \\
\hline Asia & 5.13 & 0.45 & 1.1 & -0.43 \\
\hline Mena & 1.44 & 6.03 & 0.91 & 0.65 \\
\hline PECO & 2.01 & 1.23 & 0.43 & 019 \\
\hline OECD & 1.36 & 0.22 & -0.46 & 1.85 \\
\hline
\end{tabular}

Table 3 : Cointegration test between the nominal exchange rate and the price ratio

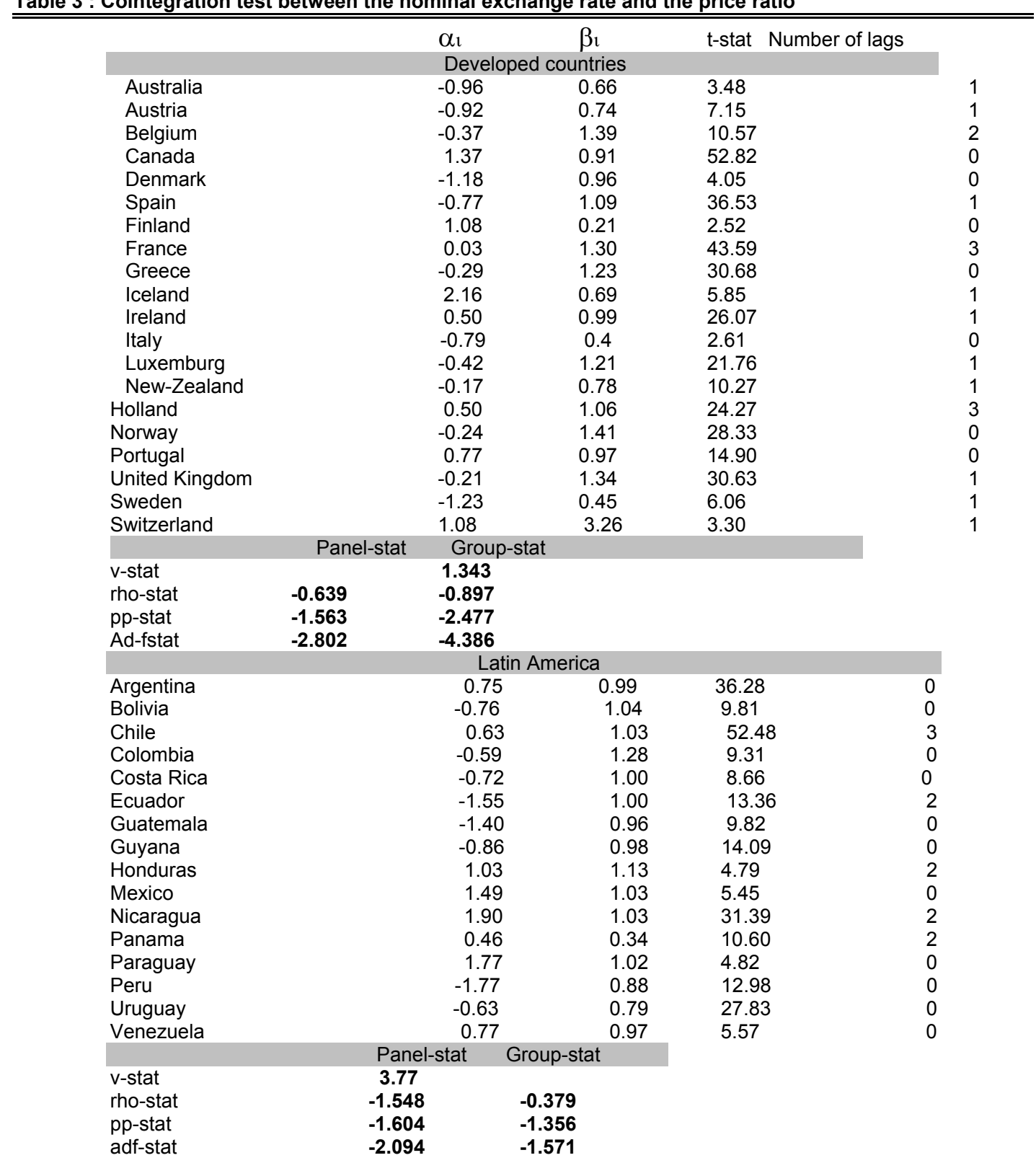


William Davidson Institute Working Paper Number 570

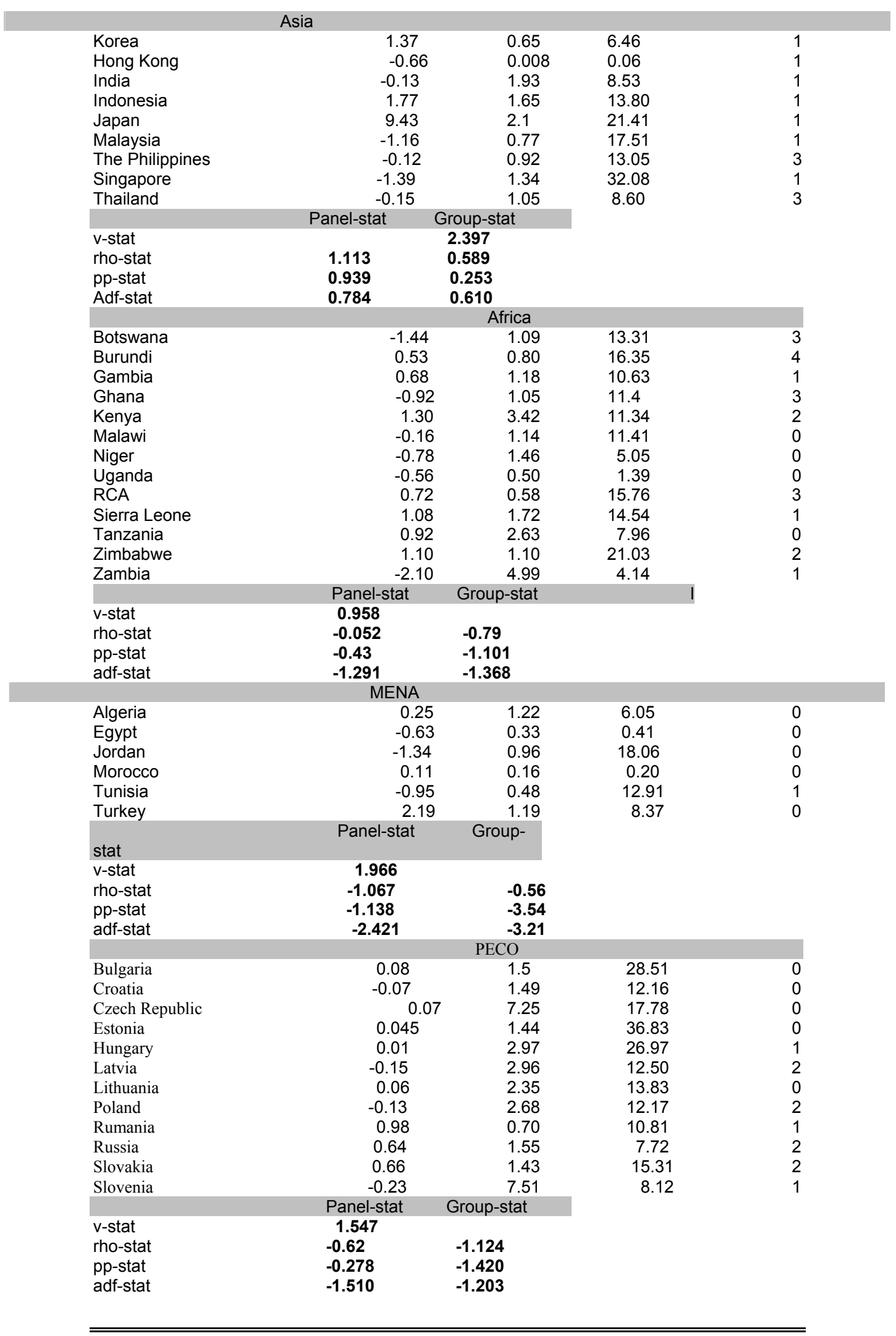


2. PPP, exchange rate regime and inflation (Pedroni, 2001)

\begin{tabular}{|c|c|c|c|c|c|}
\hline \multirow{2}{*}{\multicolumn{2}{|c|}{ Country }} & \multicolumn{2}{|c|}{ Constant } & \multicolumn{2}{|c|}{ Constante + trend } \\
\hline & & \multicolumn{2}{|c|}{ ADF-stat ${ }^{6}$} & \multicolumn{2}{|c|}{ ADF-stat } \\
\hline Australia & & -2.71 & (0) & -1.52 & (4) \\
\hline Austria & & 0.23 & $(0)$ & -1.87 & $(0)$ \\
\hline Belgium & & -0.08 & (0) & -1.78 & (0) \\
\hline Benin & & -1.12 & $(0)$ & -2.56 & $(0)$ \\
\hline Burkina Faso & & 0.11 & (4) & -3.11 & (2) \\
\hline Cameroon & & -1.45 & (0) & -2.13 & (0) \\
\hline Canada & & -2.21 & (0) & -2.45 & (3) \\
\hline Denmark & & 0.33 & (0) & -1.78 & $(0)$ \\
\hline Spain & & 0.34 & (4) & -1.85 & (1) \\
\hline Finland & & -1.18 & $(0)$ & -2.09 & (0) \\
\hline France & & 0.46 & (0) & -1.66 & (0) \\
\hline Gabon & & -1.73 & (3) & -2.47 & (0) \\
\hline Hong-Kong & & -2.80 & (4) & -2.69 & (1) \\
\hline India & & -1.05 & (0) & -2.60 & (0) \\
\hline Ireland & & -0.18 & (0) & -1.69 & (0) \\
\hline Italy & & -0.83 & (2) & -1.30 & (0) \\
\hline Japan & & 0.36 & (4) & -1.93 & (4) \\
\hline Jordan & & -0.95 & (4) & -3.10 & (1) \\
\hline Luxemburg & & -0.04 & (0) & -1.69 & (0) \\
\hline Malaysia & & -2.68 & (1) & -3.31 & (2) \\
\hline Mali & & -1.40 & (0) & -2.65 & (0) \\
\hline Morocco & & -1.52 & (0) & -2.14 & (1) \\
\hline Niger & & 0.16 & (0) & -2.74 & (0) \\
\hline Norway & & 0.57 & (4) & -2.47 & (0) \\
\hline Paraguay & & -3.37 & (3) & -1.99 & (0) \\
\hline Holland & & -0.42 & (0) & -2.17 & $(0)$ \\
\hline R. C.A & & -2.75 & (3) & -2.38 & (0) \\
\hline R. Congo & & -0.60 & (1) & -1.78 & (0) \\
\hline United Kingdom & & -3.85 & (3) & -0.95 & (3) \\
\hline Senegal & & -1.64 & $(0)$ & -2.48 & $(0)$ \\
\hline Singapore & & -1.99 & (1) & -2.36 & (2) \\
\hline Sweden & & -1.36 & (0) & -1.73 & (0) \\
\hline Tunisia & & -2.46 & (1) & -1.84 & (0) \\
\hline Australia & & -1.78 & (2) & -2.26 & (1) \\
\hline Group-ADF-stat & 2.60 & & & -4.31 & \\
\hline
\end{tabular}

Table. 4 : Stationarity tests of the TCR for countries with high inflation (Pedroni, 2001)

\begin{tabular}{lllll} 
Country & \multicolumn{2}{c}{ Constant } & Constant + trend \\
Argentina & -1.73 & $(0)$ & -2.37 & $(0)$ \\
Bolivia & -1.77 & $(0)$ & -1.75 & $(0)$ \\
Chile & -2.39 & $(1)$ & -2.08 & $(0)$ \\
Colombia & -2.26 & $(1)$ & -2.22 & $(1)$ \\
Costa Rica & -1.72 & $(0)$ & -2.30 & $(0)$ \\
Egypt & -1.94 & $(1)$ & -2.76 & $(1)$
\end{tabular}

${ }^{6}$ The number of lags is given in brackets. 
William Davidson Institute Working Paper Number 570

\begin{tabular}{lllll} 
El Salvador & -1.74 & $(0)$ & -1.34 & $(0)$ \\
Ecuador & -3.26 & $(2)$ & -2.02 & $(2)$ \\
Greece & -1.55 & $(0)$ & -1.14 & $(0)$ \\
Guatemala & -1.56 & $(0)$ & -2.03 & $(0)$ \\
Iceland & -2.40 & $(0)$ & -2.09 & $(1)$ \\
Mexico & -1.61 & $(2)$ & -3.00 & $(0)$ \\
Peru & -0.38 & $(0)$ & -0.42 & $(0)$ \\
Portugal & -2.61 & $(1)$ & -0.94 & $(1)$ \\
Switzerland & -1.91 & $(0)$ & -1.86 & $(0)$ \\
Turkey & -1.53 & $(0)$ & -2.12 & $(0)$ \\
Uruguay & -1.03 & $(0)$ & -1.31 & $(0))$ \\
Venezuela & -1.20 & $(0)$ & -2.14 & $(0)$ \\
Group-ADF-stat & $-\mathbf{1 . 5 1}$ & & $\mathbf{- 1 . 7 2}$ & \\
\hline \hline
\end{tabular}

Table. 5 : Stationarity tests of the TCR for countries with fixed exchange rate regime

\begin{tabular}{lcccc} 
& \multicolumn{2}{c}{ Constant } & Constant + trend \\
Chile & -1.62 & $(0)$ & -1.08 & $(0)$ \\
Colombia & 1.60 & $(0)$ & -2.06 & $(1)$ \\
Costa Rica & 0.91 & $(0)$ & -0.65 & $(0)$ \\
Ecuador & -1.38 & $(1)$ & -1.75 & $(0)$ \\
Egypt & -1.61 & $(0)$ & -0.81 & $(0)$ \\
Guatemala & -0.54 & $(1)$ & -1.48 & $(0)$ \\
Honduras & 2.57 & $(0)$ & -1.54 & $(0)$ \\
India & -0.43 & $(0)$ & 1.42 & $(0)$ \\
Jordan & 0.51 & $(0)$ & -0.18 & $(0)$ \\
Nicaragua & -1.41 & $(0)$ & -1.47 & $(0)$ \\
Paraguay & 1.34 & $(0)$ & -1.55 & $(0)$ \\
The Philippines & -0.10 & $(0)$ & -0.48 & $(0)$ \\
Thailand & 0.40 & $(0)$ & -1.55 & $(0)$ \\
Turkey & -1.08 & $(0)$ & -1.48 & $(0)$ \\
Uruguay & -0.66 & $(0)$ & -1.17 & $(0)$ \\
Zambia & 0.41 & $(0)$ & -2.94 & $(1)$ \\
Group-ADF-stat & & & & \\
\hline \hline
\end{tabular}

Table. 6 : Stationarity tests of the TCR for countries with floating exchange rate regime

\begin{tabular}{lcccc}
\hline & Constant & Constant + trend \\
IAustralia & -3.28 & $(0)$ & 9.00 & $(0)$ \\
Austria & -2.71 & $(1)$ & 9.09 & $(0)$ \\
Belgium & -1.91 & $(1)$ & 9.14 & $(0)$ \\
Canada & -7.65 & $(2)$ & 9.08 & $(0)$ \\
Colombia & -1.87 & $(0)$ & 9.12 & $(0)$ \\
Chile & -1.95 & $(0)$ & 9.17 & $(0)$ \\
Denmark & 1.40 & $(2)$ & 9.09 & $(0)$ \\
Ecuador & -1.47 & $(0)$ & 7.67 & $(0)$ \\
Spain & -1.95 & $(0)$ & 9.09 & $(0)$ \\
Finland & -1.66 & $(0)$ & 6.85 & $(0)$ \\
France & -3.66 & $(1)$ & 9.08 & $(0)$ \\
Greece & -1.81 & $(1)$ & 9.42 & $(0)$ \\
Guatemala & -0.38 & $(0)$ & 9.08 & $(0)$ \\
Honduras & -0.95 & $(0)$ & 7.77 & $(0)$ \\
India & -2.13 & $(2)$ & 9.25 & $(0)$ \\
Ireland & -1.90 & $(0)$ & 9.17 & $(0)$ \\
Iceland & 9.75 & $(0)$ & 9.77 & $(0)$
\end{tabular}


William Davidson Institute Working Paper Number 570

\begin{tabular}{lcccc} 
Italy & -3.03 & $(0)$ & 4.18 & $(2)$ \\
Japan & -2.33 & $(0)$ & 9.10 & $(0)$ \\
Luxemburg & -1.81 & $(0)$ & 9.37 & $(0)$ \\
Morocco & -7.05 & $(2)$ & 3.78 & $(2)$ \\
New. Zealand & -2.30 & $(1)$ & 2.05 & $(0)$ \\
Norway & -2.04 & $(0)$ & 9.08 & $(0)$ \\
Paraguay & -1.83 & $(0)$ & 9.08 & $(0)$ \\
Holland & -1.75 & $(0)$ & 9.10 & $(0)$ \\
Peru & -2.94 & $(1)$ & 9.10 & $(0)$ \\
Portugal & -6.73 & $(2)$ & 9.07 & $(0)$ \\
R. C.A & -2.82 & $(1)$ & 9.08 & $(0)$ \\
United Kingdom & -2.81 & $(1)$ & 9.10 & $(0)$ \\
Sweden & -7.55 & $(2)$ & 9.09 & $(0)$ \\
Switzerland & 1.53 & $(0)$ & 9.08 & $(0)$ \\
Thailand & -2.06 & $(0)$ & 9.51 & $(0)$ \\
Tunisia & -3.04 & $(0)$ & 9.09 & $(0)$ \\
Turkey & -0.70 & $(0)$ & 9.10 & $(0)$ \\
Uruguay & -5.57 & $(2)$ & 9.18 & $(0)$ \\
Group-ADF-stat & & & & \\
\hline \hline
\end{tabular}




\section{Appendix 2: Procedure of country classification according to the exchange rate regime}

Table. 8 : Evolution of exchange rate regimes

\begin{tabular}{|c|c|c|c|c|c|c|c|c|c|c|c|c|c|c|c|c|c|c|c|c|c|c|c|c|c|c|c|c|}
\hline & 1971 & 1972 & 1973 & 1974 & 1975 & 1976 & 1977 & 1978 & 1979 & 1980 & 1981 & 1982 & 1983 & 1984 & 1985 & 1986 & 1987 & 1988 & 1989 & 1990 & 1991 & 1992 & 1993 & 1994 & 1995 & 1996 & 1997 & 1998 \\
\hline ALGERIA & $f x$ & $\mathrm{fx}$ & nd & nd & $\mathrm{i}$ & $f$ & $f$ & $f$ & $f$ & $f$ & $f$ & $f$ & $f$ & $f$ & $f$ & $f$ & $f$ & $f$ & $f$ & $f$ & $f$ & $f$ & $f$ & $f$ & $f$ & $f$ & $f$ & $f$ \\
\hline ARGENTINA & nd & nd & nd & nd & nd & nd & nd & nd & nd & nd & nd & nd & nd & nd & nd & nd & nd & nd & $f x$ & $f$ & $f$ & $f x$ & $f x$ & $f x$ & $f x$ & $f x$ & $f x$ & $f x$ \\
\hline BOLIVIA & nd & nd & nd & nd & nd & nd & nd & nd & nd & nd & nd & nd & nd & $f x$ & $f$ & $\mathrm{f}$ & $\mathrm{i}$ & nd & $f$ & $f$ & $f$ & $f$ & $f$ & $f$ & $\mathrm{i}$ & $f$ & $f$ & $f$ \\
\hline BOTSAWANA & $f x$ & $f x$ & $f x$ & $f x$ & $f x$ & $f x$ & $f x$ & $f x$ & $f x$ & $f x$ & $f x$ & $f x$ & $f x$ & $\mathrm{i}$ & $f x$ & $\mathrm{i}$ & $f x$ & $f x$ & $f x$ & $f x$ & $f x$ & $f x$ & $f x$ & $f x$ & $f x$ & $\mathrm{i}$ & $f x$ & $\mathrm{i}$ \\
\hline BURANDI & $f x$ & $f x$ & $f$ & $f x$ & $f x$ & $f x$ & $f x$ & $f x$ & $f x$ & $f x$ & $f x$ & $f x$ & $f x$ & $f$ & $f$ & $f$ & $f$ & $f$ & $f$ & $f$ & $f$ & $f$ & $f$ & $f$ & $f$ & $f$ & $f$ & $f$ \\
\hline CHILE & $f x$ & $f x$ & $f x$ & $f x$ & $f x$ & $f x$ & nd & nd & $f x$ & $f x$ & $f x$ & $f x$ & $f x$ & $\mathrm{i}$ & $f$ & $f$ & $f$ & $\mathrm{i}$ & $f$ & $\mathrm{i}$ & $f$ & $f$ & $f$ & $\mathrm{i}$ & $f$ & $\mathrm{i}$ & $\mathrm{i}$ & $f$ \\
\hline COLOMMBIA & $\mathrm{fx}$ & $\mathrm{fx}$ & $\mathrm{fx}$ & $\mathrm{fx}$ & $\mathrm{fx}$ & $\mathrm{fx}$ & $\mathrm{fx}$ & $\mathrm{fx}$ & $\mathrm{fx}$ & $\mathrm{fx}$ & $\mathrm{fx}$ & $\mathrm{fx}$ & $\mathrm{fx}$ & $\mathrm{fx}$ & fx & $\mathrm{f}$ & $\mathrm{fx}$ & $\mathrm{fx}$ & $\mathrm{i}$ & $\mathrm{i}$ & $\mathrm{i}$ & $\mathrm{i}$ & $\mathrm{i}$ & $f$ & $f$ & $\mathrm{f}$ & $\mathrm{f}$ & $f$ \\
\hline KOREA & $\mathrm{fi}$ & $f x$ & $f x$ & $f x$ & $f x$ & $f x$ & $\mathrm{fx}$ & $f x$ & $\mathrm{fx}$ & $\mathrm{f}$ & $\mathrm{i}$ & $f x$ & $\mathrm{fx}$ & $\mathrm{i}$ & $\mathrm{i}$ & $f$ & $\mathrm{i}$ & $f x$ & $\mathrm{fx}$ & $\mathrm{i}$ & $\mathrm{i}$ & $\mathrm{i}$ & $f x$ & $\mathrm{i}$ & $\mathrm{i}$ & $\mathrm{i}$ & $f$ & $f$ \\
\hline COTA RICA & $f x$ & $f x$ & $f x$ & $f x$ & $\mathrm{fx}$ & $\mathrm{fx}$ & $f x$ & $\mathrm{fx}$ & $f x$ & $f x$ & $\mathrm{fx}$ & $\mathrm{fx}$ & $\mathrm{fx}$ & $\mathrm{fx}$ & $\mathrm{fx}$ & $\mathrm{i}$ & $\mathrm{fx}$ & $f x$ & $\mathrm{fx}$ & $f x$ & $f x$ & $f x$ & $f x$ & $f x$ & $\mathrm{i}$ & $f x$ & $f x$ & $\mathrm{fx}$ \\
\hline EGYPT & $f x$ & $f x$ & $f x$ & $\mathrm{fx}$ & $\mathrm{fx}$ & $\mathrm{fx}$ & $\mathrm{fx}$ & $\mathrm{fx}$ & $f x$ & $\mathrm{fx}$ & $\mathrm{fx}$ & $\mathrm{fx}$ & $f x$ & $f x$ & $f x$ & $f x$ & $f x$ & $f x$ & $f$ & $f$ & $f$ & $f x$ & $\mathrm{fx}$ & $\mathrm{i}$ & $f x$ & $f x$ & $\mathrm{fx}$ & $\mathrm{fx}$ \\
\hline ECUADOR & $\mathrm{fx}$ & $f x$ & $f x$ & $f x$ & $f x$ & $f x$ & $f x$ & $f x$ & $f x$ & $f x$ & $f x$ & $\mathrm{fx}$ & $\mathrm{fx}$ & $\mathrm{fx}$ & $f x$ & $\mathrm{i}$ & $f x$ & $\mathrm{i}$ & $\mathrm{i}$ & $\mathrm{i}$ & $\mathrm{i}$ & $f$ & $\mathrm{i}$ & $f$ & $f$ & $f$ & $f$ & $f$ \\
\hline GAMBIA & $f x$ & $\mathrm{i}$ & $\mathrm{i}$ & $\mathrm{i}$ & $\mathrm{i}$ & $\mathrm{i}$ & $\mathrm{i}$ & $\mathrm{i}$ & $\mathrm{i}$ & $\mathrm{i}$ & $\mathrm{i}$ & $\mathrm{i}$ & $f$ & $f$ & $f$ & $f$ & $f$ & $f$ & $f$ & $f$ & $f$ & $f$ & $f$ & $f$ & $\mathrm{i}$ & $f$ & $\mathrm{i}$ & $f$ \\
\hline GANA & $f x$ & $f x$ & $f x$ & $f x$ & $f x$ & $f x$ & $\mathrm{fx}$ & $f x$ & $\mathrm{fx}$ & $\mathrm{fx}$ & $f x$ & $f x$ & $\mathrm{i}$ & $\mathrm{fx}$ & $\mathrm{fx}$ & $\mathrm{i}$ & $f x$ & $\mathrm{fx}$ & $\mathrm{fx}$ & $\mathrm{fx}$ & $f x$ & $f x$ & $\mathrm{i}$ & $\mathrm{i}$ & $\mathrm{i}$ & $\mathrm{i}$ & $\mathrm{i}$ & $\mathrm{i}$ \\
\hline GUATUMALA & $\mathrm{fx}$ & $\mathrm{fx}$ & $\mathrm{fx}$ & $\mathrm{fx}$ & $\mathrm{fx}$ & $\mathrm{fx}$ & $\mathrm{fx}$ & $\mathrm{fx}$ & $\mathrm{fx}$ & $\mathrm{fx}$ & $\mathrm{fx}$ & $\mathrm{fx}$ & $\mathrm{fx}$ & $\mathrm{fx}$ & $\mathrm{fx}$ & $\mathrm{i}$ & $\mathrm{fx}$ & $\mathrm{i}$ & $f$ & $\mathrm{f}$ & $\mathrm{i}$ & $\mathrm{f}$ & $\mathrm{f}$ & $\mathrm{f}$ & $\mathrm{f}$ & $\mathrm{f}$ & $\mathrm{f}$ & $f$ \\
\hline GUYANA & $\mathrm{i}$ & $\mathrm{i}$ & 1 & $\mathrm{i}$ & $\mathrm{i}$ & $\mathrm{fx}$ & $f x$ & $f x$ & $f x$ & $\mathrm{fx}$ & $\mathrm{i}$ & $f x$ & $f x$ & $f$ & $f$ & $\mathrm{i}$ & $f x$ & $f x$ & $f x$ & $f$ & $f$ & $f$ & $f$ & $f$ & $f$ & $f$ & $f$ & $f$ \\
\hline HONDORAS & $f x$ & $f x$ & $f x$ & $f x$ & $f x$ & $\mathrm{fx}$ & $\mathrm{fx}$ & $\mathrm{fx}$ & $f x$ & $f x$ & $\mathrm{fx}$ & $\mathrm{fx}$ & $\mathrm{fx}$ & $\mathrm{fx}$ & $\mathrm{fx}$ & $\mathrm{i}$ & $f x$ & $f x$ & $f x$ & $f$ & $\mathrm{i}$ & $\mathrm{i}$ & $f$ & $f$ & $f$ & $f$ & $f$ & $f$ \\
\hline INDIA & $f x$ & $f x$ & $f x$ & $f x$ & $f x$ & $f x$ & $f x$ & $f x$ & $f x$ & $f x$ & $f x$ & $f x$ & $f x$ & $f x$ & $f x$ & $f x$ & $f x$ & $f x$ & $f x$ & $f x$ & $f x$ & $f x$ & $f x$ & $f x$ & $f x$ & $f x$ & $f x$ & $f x$ \\
\hline INDONISIA & $\mathrm{fx}$ & $f x$ & $f x$ & $f x$ & $f x$ & $f x$ & $f x$ & $\mathrm{i}$ & $f x$ & $f x$ & $f x$ & $f x$ & $\mathrm{i}$ & $\mathrm{i}$ & $\mathrm{i}$ & $\mathrm{i}$ & $f x$ & $\mathrm{i}$ & $\mathrm{fx}$ & $f x$ & $\mathrm{i}$ & $\mathrm{i}$ & $\mathrm{i}$ & $\mathrm{i}$ & $\mathrm{i}$ & $\mathrm{i}$ & $f$ & $f$ \\
\hline JORDAN & $f x$ & $f x$ & $f x$ & $f x$ & $\mathrm{fx}$ & $\mathrm{fx}$ & $f x$ & $\mathrm{i}$ & $f x$ & $\mathrm{fx}$ & $\mathrm{fx}$ & $\mathrm{fx}$ & $\mathrm{fx}$ & $f x$ & $\mathrm{i}$ & $\mathrm{i}$ & $\mathrm{i}$ & $\mathrm{i}$ & $\mathrm{i}$ & $f x$ & $f x$ & $\mathrm{i}$ & $\mathrm{fx}$ & $\mathrm{i}$ & $\mathrm{i}$ & $\mathrm{fx}$ & $\mathrm{fx}$ & $\mathrm{fx}$ \\
\hline KENYA & $\mathrm{fx}$ & $f x$ & 1 & $\mathrm{i}$ & $\mathrm{fx}$ & $\mathrm{i}$ & $\mathrm{i}$ & $f$ & $f$ & $f$ & $f$ & $f$ & $f$ & $f$ & $f$ & $f$ & $f$ & $f$ & $f$ & $f$ & $f$ & $f$ & $f$ & $f$ & $f$ & $f$ & $f$ & $f$ \\
\hline MALAWI & $\mathrm{fx}$ & $\mathrm{i}$ & $\mathrm{i}$ & $\mathrm{fx}$ & $\mathrm{fx}$ & $\mathrm{fx}$ & $\mathrm{fx}$ & $\mathrm{fx}$ & $\mathrm{fx}$ & $\mathrm{fx}$ & $\mathrm{fx}$ & $\mathrm{i}$ & $\mathrm{i}$ & $\mathrm{i}$ & $\mathrm{i}$ & $\mathrm{i}$ & $f$ & $f$ & $\mathrm{i}$ & $\mathrm{i}$ & $\mathrm{i}$ & $f$ & $f$ & $f$ & $\mathrm{i}$ & $\mathrm{fx}$ & $f$ & $f$ \\
\hline MALAYSIA & $\mathrm{i}$ & $\mathrm{i}$ & $f$ & $f$ & $\mathrm{i}$ & $\mathrm{i}$ & $\mathrm{i}$ & $f$ & $\mathrm{i}$ & $\mathrm{i}$ & $\mathrm{i}$ & $\mathrm{i}$ & $\mathrm{i}$ & $\mathrm{i}$ & $\mathrm{i}$ & $\mathrm{i}$ & $\mathrm{i}$ & $\mathrm{i}$ & $\mathrm{i}$ & $\mathrm{i}$ & $\mathrm{i}$ & $\mathrm{i}$ & $\mathrm{i}$ & $\mathrm{i}$ & $\mathrm{i}$ & $\mathrm{i}$ & $f$ & $f$ \\
\hline MOROCCO & $f x$ & $f x$ & $\mathrm{i}$ & $\mathrm{i}$ & $\mathrm{i}$ & $\mathrm{i}$ & $\mathrm{i}$ & $f$ & $f$ & $f$ & $f$ & $f$ & $f$ & $f$ & $f$ & $\mathrm{i}$ & $f$ & $f$ & $f$ & $f$ & $f$ & $f$ & $f$ & $f$ & $f$ & $f$ & $f$ & $f$ \\
\hline MEXICO & $\mathrm{fx}$ & $\mathrm{fx}$ & $\mathrm{fx}$ & $\mathrm{fx}$ & $\mathrm{fx}$ & $\mathrm{fx}$ & $\mathrm{fx}$ & $\mathrm{fx}$ & $\mathrm{fx}$ & $\mathrm{fx}$ & $\mathrm{fx}$ & $i$ & $\mathrm{i}$ & $\mathrm{i}$ & $\mathrm{i}$ & $\mathrm{i}$ & $\mathrm{f}$ & $\mathrm{fx}$ & $\mathrm{i}$ & $\mathrm{i}$ & $\mathrm{fx}$ & $\mathrm{fx}$ & $\mathrm{fx}$ & $f$ & $\mathrm{f}$ & $\mathrm{f}$ & $\mathrm{f}$ & $f$ \\
\hline NICARAGUA & $f x$ & $f x$ & $f x$ & $f x$ & $f x$ & $f x$ & $f x$ & $f x$ & $f x$ & $f x$ & $f x$ & $f x$ & $f x$ & $f x$ & $f x$ & $f x$ & $f x$ & nd & nd & nd & nd & nd & nd & nd & nd & nd & nd & nd \\
\hline NIGERIA & $f x$ & $f x$ & $f x$ & $f x$ & $f x$ & $f x$ & $f x$ & $f x$ & $f x$ & $f x$ & $f x$ & $\mathrm{i}$ & $\mathrm{i}$ & $\mathrm{i}$ & $\mathrm{i}$ & $\mathrm{i}$ & $\mathrm{i}$ & $\mathrm{i}$ & $\mathrm{i}$ & $f x$ & $\mathrm{i}$ & $\mathrm{i}$ & $\mathrm{i}$ & $\mathrm{i}$ & $f x$ & $\mathrm{fx}$ & $\mathrm{i}$ & $f x$ \\
\hline UGANDA & $\mathrm{fx}$ & $\mathrm{fx}$ & $\mathrm{fx}$ & $\mathrm{fx}$ & $\mathrm{fx}$ & $\mathrm{fx}$ & $\mathrm{fx}$ & $\mathrm{fx}$ & $\mathrm{fx}$ & $\mathrm{fx}$ & $\mathrm{fx}$ & $\mathrm{fx}$ & $\mathrm{fx}$ & $\mathrm{fx}$ & $\mathrm{fx}$ & $\mathrm{fx}$ & $\mathrm{fx}$ & $\mathrm{fx}$ & $\mathrm{fx}$ & nd & nd & nd & $\mathrm{i}$ & $\mathrm{i}$ & $\mathrm{i}$ & $\mathrm{i}$ & $\mathrm{i}$ & $\mathrm{i}$ \\
\hline PARAGUAY & $\mathrm{fx}$ & $f x$ & $f x$ & $\mathrm{fx}$ & $\mathrm{fx}$ & $\mathrm{fx}$ & $f x$ & $\mathrm{fx}$ & $f x$ & $f x$ & $\mathrm{fx}$ & $\mathrm{fx}$ & $\mathrm{fx}$ & $f x$ & $\mathrm{i}$ & $\mathrm{i}$ & $\mathrm{fx}$ & $\mathrm{fx}$ & $f$ & $\mathrm{i}$ & $\mathrm{i}$ & $\mathrm{i}$ & $\mathrm{i}$ & $\mathrm{i}$ & $\mathrm{i}$ & $\mathrm{i}$ & $\mathrm{i}$ & $f$ \\
\hline PHILIPPINES & $f x$ & $f x$ & $f x$ & $\mathrm{fx}$ & $\mathrm{fx}$ & $\mathrm{fx}$ & $\mathrm{fx}$ & $\mathrm{fx}$ & $f x$ & $\mathrm{fx}$ & $\mathrm{fx}$ & $\mathrm{fx}$ & $\mathrm{fx}$ & nd & nd & nd & $\mathrm{fx}$ & $f x$ & $\mathrm{fx}$ & $\mathrm{fx}$ & $\mathrm{fx}$ & $f x$ & $f x$ & $\mathrm{fx}$ & $\mathrm{fx}$ & $\mathrm{fx}$ & $\mathrm{fx}$ & $f x$ \\
\hline COSTA-RICA & $\mathrm{fx}$ & $f x$ & $f x$ & $f x$ & $f x$ & $f x$ & $f x$ & $\mathrm{i}$ & $\mathrm{fx}$ & $\mathrm{fx}$ & $\mathrm{i}$ & $\mathrm{i}$ & $\mathrm{i}$ & $\mathrm{i}$ & $\mathrm{i}$ & $\mathrm{i}$ & $\mathrm{i}$ & $\mathrm{i}$ & $\mathrm{i}$ & $f x$ & $\mathrm{i}$ & $\mathrm{i}$ & $\mathrm{i}$ & $\mathrm{i}$ & $\mathrm{i}$ & $\mathrm{i}$ & $\mathrm{i}$ & $\mathrm{i}$ \\
\hline SINGAPORE & $\mathrm{i}$ & $\mathrm{i}$ & $\mathrm{i}$ & $\mathrm{i}$ & $\mathrm{i}$ & $\mathrm{i}$ & $\mathrm{i}$ & $\mathrm{i}$ & $\mathrm{i}$ & $\mathrm{i}$ & $\mathrm{i}$ & $\mathrm{i}$ & $\mathrm{i}$ & $\mathrm{i}$ & $\mathrm{i}$ & $\mathrm{i}$ & $\mathrm{i}$ & $\mathrm{i}$ & $\mathrm{i}$ & $\mathrm{i}$ & $\mathrm{i}$ & $\mathrm{i}$ & $\mathrm{i}$ & $\mathrm{i}$ & $\mathrm{i}$ & $f x$ & $\mathrm{i}$ & $\mathrm{i}$ \\
\hline
\end{tabular}




\begin{tabular}{|c|c|c|c|c|c|c|c|c|c|c|c|c|c|c|c|c|c|c|c|c|c|c|c|c|c|c|c|c|}
\hline SIRALEONE & fx & $\mathrm{i}$ & $\mathrm{i}$ & $f x$ & $\mathrm{i}$ & $\mathrm{i}$ & $\mathrm{i}$ & $\mathrm{i}$ & $\mathrm{i}$ & $\mathrm{i}$ & $\mathrm{i}$ & $f$ & $f$ & $f x$ & $f$ & $f$ & $f$ & $f$ & $f$ & $f$ & $f$ & $f$ & $f$ & $f$ & $f$ & $f$ & $f$ & $f$ \\
\hline TANZANIA & $f x$ & $f x$ & $\mathrm{fx}$ & $f x$ & $f x$ & $f$ & $f$ & $f$ & $\mathrm{f}$ & $\mathrm{i}$ & $f$ & $f$ & $f$ & $f$ & $f$ & $f$ & $f$ & $f$ & $f$ & $f x$ & $f x$ & nd & $f$ & $f$ & $f$ & $\mathrm{f}$ & $\mathrm{f}$ & $f$ \\
\hline THAILAND & $f x$ & fx & fx & fx & $f x$ & $f x$ & $f x$ & $\mathrm{fx}$ & $f x$ & $f x$ & $f x$ & $f x$ & $f x$ & $f x$ & $f x$ & $\mathrm{i}$ & $f x$ & $f x$ & $f x$ & $f x$ & $f x$ & $f x$ & $f x$ & $f x$ & $f x$ & $f x$ & $f x$ & $f x$ \\
\hline TUNISIA & $\mathrm{fx}$ & $f x$ & $\mathrm{i}$ & $\mathrm{i}$ & $\mathrm{i}$ & $\mathrm{i}$ & $\mathrm{fx}$ & fx & $f x$ & $\mathrm{i}$ & $\mathrm{i}$ & $\mathrm{i}$ & $\mathrm{i}$ & $\mathrm{i}$ & $\mathrm{i}$ & $\mathrm{i}$ & $\mathrm{i}$ & $\mathrm{i}$ & $\mathrm{i}$ & $\mathrm{fx}$ & $\mathrm{i}$ & $\mathrm{i}$ & $\mathrm{i}$ & $\mathrm{i}$ & $\mathrm{i}$ & $\mathrm{i}$ & $\mathrm{i}$ & $\mathrm{i}$ \\
\hline TURKEY & $\mathrm{fx}$ & $f x$ & $f x$ & $f x$ & $f x$ & $f x$ & $\mathrm{fx}$ & $\mathrm{fx}$ & $\mathrm{fx}$ & $f x$ & $f x$ & $\mathrm{fx}$ & $\mathrm{fx}$ & $f x$ & $f x$ & $f x$ & $f x$ & $f x$ & $f x$ & $f x$ & $f x$ & $f x$ & $\mathrm{fx}$ & $\mathrm{fx}$ & $f x$ & $f x$ & $f x$ & $f x$ \\
\hline URUGUAY & $\mathrm{fx}$ & $f x$ & $f x$ & $f x$ & $\mathrm{fx}$ & $f x$ & $\mathrm{fx}$ & $\mathrm{fx}$ & $f x$ & $f x$ & $\mathrm{fx}$ & $f x$ & $\mathrm{fx}$ & $\mathrm{fx}$ & $\mathrm{i}$ & $\mathrm{i}$ & $\mathrm{i}$ & $\mathrm{i}$ & $f$ & $f$ & $f$ & $f$ & $\mathrm{f}$ & $\mathrm{f}$ & $f$ & $\mathrm{f}$ & $f$ & $f$ \\
\hline ZAMBABWE & $\mathrm{fx}$ & $\mathrm{fx}$ & $f x$ & $f x$ & $\mathrm{fx}$ & $\mathrm{fx}$ & $f x$ & $\mathrm{fx}$ & $f x$ & $f x$ & $\mathrm{fx}$ & $\mathrm{i}$ & $\mathrm{i}$ & $f$ & $\mathrm{i}$ & $\mathrm{i}$ & $\mathrm{i}$ & $\mathrm{i}$ & $\mathrm{i}$ & $\mathrm{i}$ & $f$ & $\mathrm{i}$ & $f$ & $f$ & $\mathrm{i}$ & $f$ & $f$ & nd \\
\hline ZAMBIA & $f x$ & $f x$ & $f x$ & $f x$ & $f x$ & $f x$ & $f x$ & $\mathrm{fx}$ & $f x$ & $f x$ & $\mathrm{fx}$ & $f x$ & $f x$ & $\mathrm{fx}$ & $\mathrm{fx}$ & $f x$ & $\mathrm{fx}$ & $f x$ & $\mathrm{fx}$ & $f x$ & $f x$ & $\mathrm{fx}$ & $f x$ & $\mathrm{fx}$ & $f x$ & $\mathrm{i}$ & $f x$ & $\mathrm{i}$ \\
\hline
\end{tabular}

Note: $n d$ means indefinite regime, $f x$ means fixed regime, $i$ means intermediate regime and $f$ means flexible regime

From the previous classification we define two exchange rate regimes : a regime of fixed exchange rate and a regime of floating exchange rate. The exchange rate regime is supposed to be fixed when nominal exchange rate is maintained constant and when the exchange reserves strongly vary. The floating exchange rate regime is characterized by

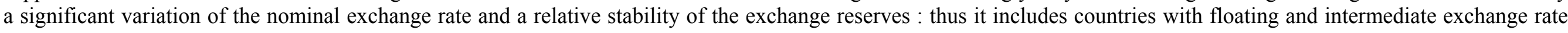

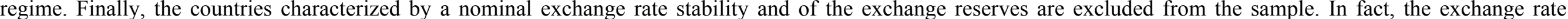

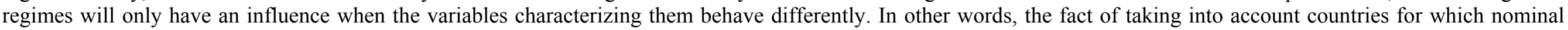
exchange rate and exchange reserves are stable could biased econometric results towards the absence of a significant effect of the exchange rate regimes. 


\section{DAVIDSON INSTITUTE WORKING PAPER SERIES - Most Recent Papers}

The entire Working Paper Series may be downloaded free of charge at: www.wdi.bus.umich.edu

CURRENT AS OF 5/6/03

\begin{tabular}{|c|c|c|}
\hline Publication & Authors & Date \\
\hline $\begin{array}{l}\text { No. 570: A re-examination of the Purchasing Power Parity using non- } \\
\text { stationary dynamic panel methods: a comparative approach for } \\
\text { developing and developed countries }\end{array}$ & Imed Drine and Christophe Rault & May 2003 \\
\hline $\begin{array}{l}\text { No. 569: How Important is Ownership in a Market with Level Playing } \\
\text { Field? The Indian Banking Sector Revisited }\end{array}$ & $\begin{array}{l}\text { Sumon Kumar Bhaumik and } \\
\text { Ralitza Dimova }\end{array}$ & May 2003 \\
\hline $\begin{array}{l}\text { No. 568: On Types of Trade, Adjustment of Labor and Welfare Gains } \\
\text { During Asymmetric Liberalizations }\end{array}$ & Yener Kandogan & May 2003 \\
\hline $\begin{array}{l}\text { No. 567: Technological Progress Through Trade Liberalization in } \\
\text { Transition Countries }\end{array}$ & Yener Kandogan & May 2003 \\
\hline $\begin{array}{l}\text { No. 566: Intra-industry Trade of Transition Countries: Trends and } \\
\text { Determinants }\end{array}$ & Yener Kandogan & May 2003 \\
\hline $\begin{array}{l}\text { No. 565: Local Protectionism and Regional Specialization: Evidence } \\
\text { from China's Industries }\end{array}$ & $\begin{array}{l}\text { Chong-En Bai, Yingjuan Du, } \\
\text { Zhigang Tao, Sarah Y. Tong }\end{array}$ & May 2003 \\
\hline No. 564: Corporate Governance and Market Valuation in China & $\begin{array}{l}\text { Chong-En Bai, Qiao Liu, Joe Lu, } \\
\text { Frank M. Song, and Junxi Zhang }\end{array}$ & May 2003 \\
\hline $\begin{array}{l}\text { No. 563: Revenue Sharing and Control Rights in Team Production: } \\
\text { Theories and Evidence From Joint Ventures }\end{array}$ & $\begin{array}{l}\text { Chong-En Bai, Zhigang Tao, and } \\
\text { Changqi Wu }\end{array}$ & May 2003 \\
\hline $\begin{array}{l}\text { No. 562: Financial Dependence, Stock Market Liberalizations and } \\
\text { Growth }\end{array}$ & Nandini Gupta and Kathy Yuan & May 2003 \\
\hline $\begin{array}{l}\text { No. 561: Growth and Regional Inequality in China During the Reform } \\
\text { Era }\end{array}$ & Derek Jones, Cheng Li and Owen & May 2003 \\
\hline $\begin{array}{l}\text { No. 560: Choice of Ownership Structure and Firm Performance: } \\
\text { Evidence from Estonia }\end{array}$ & $\begin{array}{l}\text { Derek Jones, Panu Kalmi, Niels } \\
\text { Mygind }\end{array}$ & May 2003 \\
\hline No. 559: Explaining Postcommunist Economic Performance & Lawrence P. King & May 2003 \\
\hline $\begin{array}{l}\text { No. 558: Tax Structure and the FDI: The Deterrent Effects of } \\
\text { Complexity and Uncertainty }\end{array}$ & $\begin{array}{l}\text { Kelly Edmiston, Shannon Mudd } \\
\text { and Neven Valev }\end{array}$ & Apr. 2003 \\
\hline No. 557: Provincial Protectionism & Konstantin Sonin & Apr. 2003 \\
\hline $\begin{array}{l}\text { No. 556: Nominal and Real Convergence in Estonia: The Balassa- } \\
\text { Samuelson (dis)connection }\end{array}$ & Balázs Égert & Apr. 2003 \\
\hline $\begin{array}{l}\text { No. 555: Banks-Firms Nexus under the Currency Board: Empirical } \\
\text { Evidence from Bulgaria }\end{array}$ & $\begin{array}{l}\text { Nikolay Nenovsky, Evgeni Peev } \\
\text { and Todor Yalamov }\end{array}$ & Apr. 2003 \\
\hline $\begin{array}{l}\text { No. 554: To Steal or Not to Steal: Firm Attributes, Legal Environment, } \\
\text { and Valuation }\end{array}$ & Art Durnev and E. Han Kim & Apr. 2003 \\
\hline No. 553: Corporate Stability and Economic Growth & $\begin{array}{l}\text { Kathy S. He, Randall Morck and } \\
\text { Bernard Yeung }\end{array}$ & Apr. 2003 \\
\hline $\begin{array}{l}\text { No. 552: So Many Rocket Scientists, So Few Marketing Clerks: } \\
\text { Occupational Mobility in Times of Rapid Technological Change }\end{array}$ & $\begin{array}{l}\text { Nauro F. Campos and Aurelijus } \\
\text { Dabušinskas }\end{array}$ & Mar. 2003 \\
\hline $\begin{array}{l}\text { No. 551: Determinants of Interregional Mobility in Russia: Evidence } \\
\text { from Panel Data }\end{array}$ & $\begin{array}{l}\text { Yuri Andrienko and Sergei } \\
\text { Guriev }\end{array}$ & Feb. 2003 \\
\hline $\begin{array}{l}\text { No. 550: Gross Job Flows in Ukraine: Size, Ownership and Trade } \\
\text { Effects }\end{array}$ & $\begin{array}{l}\text { Jozef Konings, Olga Kupets and } \\
\text { Hartmut Lehmann }\end{array}$ & Mar. 2003 \\
\hline $\begin{array}{l}\text { No. 549: Technology Transfer through FDI in Top-10 Transition } \\
\text { Countries: How Important are Direct Effects, Horizontal and Vertical } \\
\text { Spillovers? }\end{array}$ & $\begin{array}{l}\text { Jože P. Damijan, Mark Knell, } \\
\text { Boris Majcen and Matija Rojec }\end{array}$ & Feb. 2003 \\
\hline $\begin{array}{l}\text { No. 548: Does Foreign Direct Investment Increase the Productivity of } \\
\text { Domestic Firms? In Search of Spillovers through Backward Linkages }\end{array}$ & Beata K. Smarzynska & Mar. 2003 \\
\hline $\begin{array}{l}\text { No. 547: Re-employment Probabilities and Wage Offer Function for } \\
\text { Russian Labor Market }\end{array}$ & Natalia V. Smirnova & Feb. 2003 \\
\hline $\begin{array}{l}\text { No. 546: Democratization's Risk Premium: Partisan and Opportunistic } \\
\text { Political Business Cycle Effects on Sovereign Ratings in Developing } \\
\text { Countries }\end{array}$ & $\begin{array}{l}\text { Steven Block, Burkhard N. } \\
\text { Schrage and Paul M. Vaaler }\end{array}$ & Feb. 2003 \\
\hline $\begin{array}{l}\text { No. 545: Structural Reforms and Competitiveness: Will Europe } \\
\text { Overtake America? }\end{array}$ & Jan Svejnar & Feb. 2003 \\
\hline
\end{tabular}

